\title{
Baseline Levels of the Chemical Parameters in the Vicinity of Quarry Industries in Igarra, Akoko Edo Local Government, Edo State
}

\author{
${\text { Onivefu Paul Asishana }{ }^{1 *} \text {, BalaAnegbe }}^{2}$ \\ ${ }^{1}$ Department of Chemistry University of Benin, Benin City, Edo State, Nigeria \\ ${ }^{2}$ Department of Chemistry, Western Delta University, Oghara, Delta State, Nigeria
}

*Corresponding Author: Onivefu Paul Asishana, Department of Chemistry University of Benin, Benin City, Edo State, Nigeria

\begin{abstract}
The present study was undertaken to study the baseline levels of the chemical parameters in the vicinity of quarry industries in Igarra, Akoko-Edo, Edo State. Three major quarries (Chestedi, F.A.U.C.Golden Ltd and Fakunle) were investigated and the River Onyami water that flows through the quarries from Ojirami dam. A total of four soil samples were collected from each quarry site at the depth of 0 $-15 \mathrm{~cm}$. Four water samples from the River Onyami were also collected. The soil and water sample were analysed for the physicochemical properties and chemical speciation of $\mathrm{Fe}, \mathrm{Zn}, \mathrm{Cu}, \mathrm{Pb}, \mathrm{Cr}$ and $\mathrm{Mn}$. A sequential extraction procedure was used that generated five different fractions (Tessier et al., 1978) into which the heavy metal could be partitioned. The total concentrations of the heavy metals in the quarry soils and water samples were calculated. The accumulated pattern for the heavy metals in the soil follows the order $\mathrm{Fe}>\mathrm{Zn}>\mathrm{Mn}>\mathrm{Cu}>\mathrm{Pb}>\mathrm{Cr}$ and the accumulated pattern for the heavy metals present in the water sample follows the pattern $\mathrm{Fe}>\mathrm{Zn}>\mathrm{Cu}>\mathrm{Mn}>\mathrm{Pb}>\mathrm{Cr}$. Iron and zinc are the most dominant heavy metals in the soil, in which iron occurs at its permissible limit while zinc, copper, manganese, lead and chromium occurs at above their permissible limit. Iron and lead occurs at above their permissible limit in the stream water while $\mathrm{Zn}, \mathrm{Cu}, \mathrm{Cr}$ and $\mathrm{Mn}$ occurs at below their permissible limit. The results of the heavy metals concentration and physicochemical properties in the soil and water were compared to WHO, NIS DPR and CCME maximum contamination/permissible limit. The Mobility Factors (MF), Environmental Risk Factors (ERF), Contamination Factors (CF), Pollution Load Index (PLI) and Geoaccumulation Index (GI) were calculated. The results obtained from this study shows that the soil can support growth and it is rich in nutrients for various uses, while the water can be used for irrigation and other domestic purposes.
\end{abstract}

\section{INTRODUCTION}

A quarry is a type of open-pit mine from which rock or minerals are extracted. Quarries are generally used for extracting building materials, such as dimension stone, construction aggregate, riprap, sand, and gravel. Limestone is a sedimentary rock composed largely of mineral calcite $\left(\mathrm{CaCO}_{3}\right)$, formed by either organic or inorganic processes (Serra, 2006).

Worldwide, quarry mining involves a variety of operations which can be environmentally disruptive if proper sitting design, construction, operation and follow-up monitoring are not provided. This is so because of the associated fine dust particles, disruptions of the earth's surface via use of explosives in the blasting process via-a-vis health hazards to site workers. Thus, it becomes imperative to assess the soil of such area to quantify the environment for sustainability (Bayramiet al., 2008).

Marble is a metamorphic rock composed essentially of calcite $\left(\mathrm{CaCO}_{3}\right)$, dolomite $\left[\mathrm{CaMg}\left(\mathrm{CO}_{3}\right)_{2}\right]$, or a combination of the two, with a fine to coarse-grained crystalline texture (Serra, 2006).

Calc-gneisses are marble with an impure composition (in other words, the ones that contain a high amount of silica, which combines with calcium and magnesium to form pyroxenes, anfiboles and olivine as well). It often happens in the metamorphism of plataformal sequences where limestones are present. Calc-gneiss occurs in association with marble in places especially around the Geoworks quarry sites (Obasi, 2012).

Limestone comes in many different varieties. Chalk is a very fine grained, porous marine limestone composed almost entirely of microscopic fossils. Travertine is a freshwater sedimentary limestone 
that has very thin, crenulated layers and is commonly formed at springs. The principal component of limestone is the mineral calcite, but limestone frequently also contains the minerals dolomite $\left[\mathrm{CaMg}\left(\mathrm{CO}_{3}\right)_{2}\right]$ and aragonite $\left(\mathrm{CaCO}_{3}\right)$. Pure calcite, dolomite, and aragonite are clear or white. However, with impurities, they can take on a variety of colours. Consequently, limestone is commonly light coloured; usually it is tan or grey. However, limestone has been found in almost every colour. The colour of limestone is due to impurities such as sand, clay, iron oxides and hydroxides, and organic materials. Colourful streaks in marble are the result of impurities such as quartz or dolomite in the original limestone, which result in the formation of minerals such as forsterite (or serpentine). If the limestone contains other materials such as sand and clay, the calcite will react with them to produce minerals such as tremolite, epidote, diopside, and grossular garnet.

The geology of Nigeria is made up of three major litho-petrological components, namely, the Basement Complex, Younger Granites, and Sedimentary Basins. The Basement Complex, which is Precambrian in age, is made up of the Migmatite-Gneiss Complex, the Schist Belts and the Older Granites. The younger granites comprise several jurassic magmatic ring complexes. They are structurally and petrologically distinct from the Older Granites. The Sedimentary Basins, containing sediment fill of Cretaceous to Tertiary ages, comprise the Niger Delta, the Benue Trough, the Chad Basin, the Sokoto Basin, the Mid-Niger (Bida/Nupe) Basin and the Dahomey Basin (Fatoye and Gideon, 2013).

According to Berry and Pistocchi (2003), early response to issues of abandoned quarry pits is to characterize the special features of the effects of blasting and other quarry operations. Efforts will then be made to control these effects when the quarry was still active, then when it becomes inactive and abandoned. For example, both active and abandoned quarry pits should be fenced off or otherwise secured to prevent people from injuring themselves there. In some cases, there may be toxins present at the site, due to the way in which the rock was extracted. In others, as the quarry slowly fills with water, it may be a tempting place to swim.

Indigenous and organized mining operations have been on-going in Nigeria since the 20th century, shortly before the 1st World War (Akande et al., 2013). However, the interest in the exploitation of these resources is on increase and have the widespread and increasing numbers of abundant mines of minerals (Limestone, Granite, Iron ore and Gemstones etc) leaving behind vast bare and degraded land, (>10 hectares per mine) at close of mining operations (FME, 1999).

There are many physical, chemical and biological technologies for treating mined out area, however the treatment to be selected will depend on severity of degradation, the site characteristics, regulatory requirements, cost and time constraints (Steffen et al., 2004). More so, the technical approaches taken to reclamation are as varied as the minerals in question and their methods of extraction. For instance, the sand and gravel operators must address the issue of post mining land use due to the proximity of most operations to urban areas. This segment of industry is recognized for its pioneering work in applying site-planning principles to mining and reclamation operations.

\subsection{Igarra Quarries (Grey Calcite)}

These quarries are in Igarra town of Akoko-Edo local government Area of Edo State about $6 \mathrm{~km}$ from the main town, it's a calcite deposit that covers an area of about 500 feet by 500 feet square meter with capacity of 50 tons crude production per day. There are three major quarry sites in Igarra, Akoko - Edo, Edo State, which are Chestedi, F.A.U.C. Golden Ltd and Fakunle quarries.

\subsection{Uses of Igarra Marble}

\subsubsection{Uses of Marble for Tiles and Chips}

Marble from Igarra is extensively used for making tiles of assorted types in Nigeria. Marble tiles for flooring are commonly used in offices, homes, Industries and corporate institutions especially where aesthetic, luxurious and exquisitely unique value is appreciated. Tiles made from marble are either glazed (polished) or unglazed. The polished types provide glistering appearance and are highly priced while unpolished types lack exquisite finishing and are relatively low cost. Their tensile and compressive strengths are high, an indication of their absolute resilience and durability properties. 


\subsubsection{Use of Marble as an Ingredient in Making Paints}

In paint making, certain physical and chemical specifications must be met. Essential physical requirements include good white colours, small sized particles (98\% passing through 325 mesh) and absence of hard particles. Standard chemical specifications provide that AL2O3> 2wt $\%, \mathrm{MgO}+$ $\mathrm{SiO} 2>75 \mathrm{w} \%$ and LOI (Loss on Ignition) must be within the range of $4-8 \mathrm{wt} \%$. The marble from Igarra satisfies the physical specifications but show contrast in their chemical requirements. Analysis indicates that $\mathrm{AL} 2 \mathrm{O} 3<1 \mathrm{wt} \%(0.67), \mathrm{MgO}+\mathrm{SiO} 2<15 \mathrm{wt} \%$ and $\mathrm{LOI}>32 \mathrm{wt} \%$. The chemical difference in $\mathrm{MgO}+\mathrm{SiO} 2$ and LOI over the required specification implies that when used for paint manufacturing, the product will not only be susceptible to quick fading on the wall but also lead to low quantity due to increased water content. The marble is therefore not adequately suitable for paint making (Robert, 1979). However, paint manufacturers always beat their market by individually setting their standards so long as their brands of paint satisfy their quality, their customers and in conformity with their production formulations and so long as their advertorial jingles impress the prospective buyers of their products (Obasi and Isife, 2012).

\subsubsection{Marble for Cement Manufacturing}

The basic raw materials for Portland cement $(\mathrm{PC})$ making are lime $(\mathrm{CaO})$, silica $(\mathrm{SiO} 2)$, alumina (AL2O3) magnesia $(\mathrm{MgO})$ and trisulphide (SO3) derivable chemically from either marble or limestone. The chemical components and standard proportions required for cement production have been highlighted by Obasi and Isife(2012). The data show that the values of lime (53 wt\%), silica (4.83 wt $\%$ ) alumina $(0.67 \mathrm{wt} \%)$, are below the required standard of $63 \mathrm{wt} \%$ for lime, $22 \mathrm{wt} \%$ for silica, $6.0 \mathrm{wt} \%$ for alumina and a range of 66-102 of LSF (lime saturation factor) respectively for cement production (Rajput, 2008).Cement factories in Nigeria are sited close to limestone deposits, except the plants at Okpilla in Edo State and Obajana in Kogi State. Limestone deposits in different parts of Nigeria are in excess of 2 billion metric tonnes. The country till date imports cement because of the dearth of cement factories to meet domestic demand. Annual demand for Portland cement is about 17 million metric tonnes while domestic production stands at below 12 million metric tonnes. Although the effect of this insufficiency has been cushioned by the establishment of two cement factories by Dangote Cement Company Plc; one is located at Obajana in Kogi State which is the largest cement company in Africa and the third largest in the world with production of 10.25 million tonnes at the rate of about 1000 trucks per day and the other factory located at Ibeshe in Ogun State with 6 million tonnes per annum capacity.

Deficiency in the lime decreases the strength of the cement and gives a quick setting of the cement. Excess of it makes the cement unsound and causes it to expand and disintegrate. A right proportion of lime makes the cement sound and strong. SiO2in excess of $22 \mathrm{wt} \%$ provides greater strength to the cement but prolongs its setting time. $\mathrm{SiO} 2$ imparts strength to the cement due to formation of dicalcium (2CaO.SiO2) and tricalcium (3CaO.SiO2) silicate. Cement production requires lateritic iron oxide in amounts generally acceptable. The marble at Igarra lacks these essential ingredients needed for cement making. The Lime Saturation Factor (LSF) must not be greater than $102 \%$ or less than 66 wt\% (66-102wt \%) range in the production of cement. The LSF (Lime Saturation Factor) for the Igarra marble $361.36 \%$. This value is higher than the maximum value of $102 \%$ and can cause the over burning of $\mathrm{CaO}$ (Rajput, 2008). Based on these analyses, the marble from Igarra becomes unsuitable for cement production (Obasi and Isife, 2012).

The Igarra marble is also used for outdoor sculpture and for sculpture bases. In the areas of architecture, it is used in exterior walls and veneers, staircases and walkways. Marble is susceptible to weathering and may require some treatment to avoid deterioration when eternally exposed. It can be applied in the making of electrical insulators, china wares, and in decorative construction. Marble is equally used in such areas like kitchens, butchers tables and tombs where the strength of the materials is properly assured. In the recent time, marble chips are used in lawns and gardens.

\subsubsection{Heavy Metals in the Vicinity of Quarry Industries}

While many heavy metals are essential elements at low levels of concentration, they can exert toxic effects at concentrations higher than permitted in the environment (Anegbeet al., 2014). They may be volatilized to the atmosphere, especially during dry seasons (Okuo and Okolo, 2011). 


\subsubsection{Environmental Impact of Quarrying in Surrounding Communities}

There has been a tremendous increase in the level of industrial activities (such as mining) and vehicular traffic in most Nigerian cities. Most of the industrial process involved the use of chemicals that are prone to emit VOCs into the atmosphere (Okuo and Olumayede, 2010). And according to Omosanya and Ajibade(2011), the environmental impacts of quarrying on the surrounding communities are;

- Boulders and gravels produced during quarrying, some of them do travel in the air during blasting thereby constituting a major hazard to nearby settlers.

- Dust produced during the quarrying work has contributed hugely to air pollution. Dusts can be seen on the vegetation some distances away from the Quarry.

- Various degree of havoc caused by the Quarrying activity, such as collapsing of the buildings around them.

\subsection{Aim of the Studies}

The aim of this study is to know the baseline levels of the chemical parameter in the vicinity of quarry industries (Chestedi, F.A.U.C. Golden Ltd and Fakunle quarries) in Igarra, Akoko Edo, Edo State.

\subsection{Objective of the Study}

The main objectives of this research are:

- Collection of composite soil samples from each of the three quarries (Chestedi, F.A.U.C. Golden Ltd and Fakunle coded as Site 1, Site 2 and Site 3),

- Collection of composite water samples from the River Onyami water that flows through the quarry,

- Identification of some important physicochemical parameters in the quarry soils and the River Onyami water around the quarry,

- Fractionating the quarry soil samples for heavy metals analysis such as ( $\mathrm{Fe}, \mathrm{Zn}, \mathrm{Cu}, \mathrm{Mn}, \mathrm{Pb}$ and $\mathrm{Cr})$,

- Analysing the stream water samples for heavy metals such as ( $\mathrm{Fe}, \mathrm{Zn}, \mathrm{Cu}, \mathrm{Mn}, \mathrm{Pb}$ and $\mathrm{Cr}$ ),

- Subjecting the data obtained to statistical and graphical analysis.

- Determining the mobility factors (MF) of the heavy metals in the soil samples of the quarries,

- Determining the environmental risk factor (ERF) of the heavy metals in the soil samples of the quarries and

Determining the contamination factor $(\mathrm{CF})$ of the heavy metals in the soil samples of the quarries

\section{MATERiAls AND MethodS}

\subsection{Study Area}

The study area is in Igarra which lies in the geographical coordinates between Latitudes $\mathrm{N} 7^{\mathrm{O}} .16 .547^{\prime}$ and Longitudes $\mathrm{E}^{\mathrm{O}}{ }^{\mathrm{O}} .06 .467$ '. It is situated at the northern fringe of Akoko Edo Local Government Authority of Edo State, Southwest Nigeria.

The quarry industries and stream water (River Onyami, usually called Upako stream by Igarra people, and which flows from Ojirami dam through Igarra to Ososo) are in Igarra, which can be located from Geoworks Industries and they are;

- Fakunle quarry,

- F.A.U.C. Golden Ltd,

- Chestedi and

- River Onyami water. 


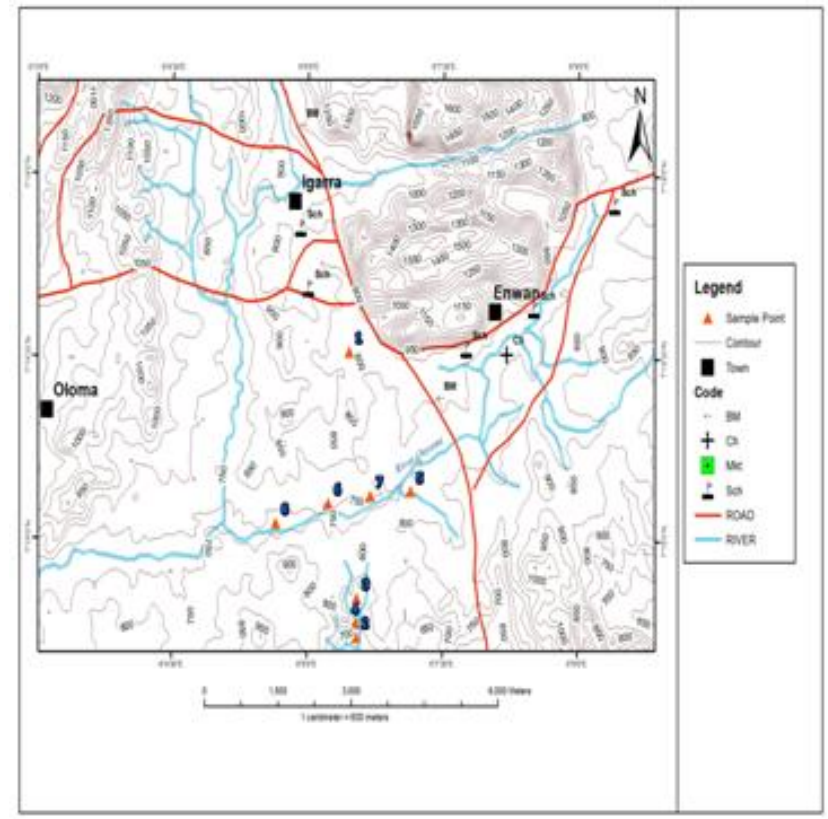

Fig1. Map of Igarra showing the study area and the sampling site

Table1. The quarries, site code and coordinate

\begin{tabular}{|c|c|c|}
\hline Quarries & Site Code & Coordinate \\
\hline Chestedi quarry & Site 1 & $\mathrm{~N}^{\mathrm{O}} 14.2868^{\prime}$ \\
& & $\mathrm{E6}^{\mathrm{O}} 06.5103^{\prime}$ \\
\hline F.A.U.C. Golden Ltd quarry & Site 2 & $\mathrm{~N}^{\mathrm{O}} 14.5205^{\prime}$ \\
& & $\mathrm{E}^{\mathrm{O}} 06.5557^{\prime}$ \\
\hline Fakunle quarry & Site 3 & $\mathrm{~N}^{\mathrm{O}} 14.3004^{\prime}$ \\
& & $\mathrm{E6}^{\mathrm{O}} 06.5275^{\prime}$ \\
\hline
\end{tabular}

Table2. The stream water samples, site code, coordinate and temperature

\begin{tabular}{|c|c|c|c|}
\hline Stream Water Samples & Site Codes & Coordinate & Temperature \\
\hline $\begin{array}{c}\text { River Onyami Water } \\
\text { Sample } 1\end{array}$ & Site 5 & $\begin{array}{l}\mathrm{N}^{\mathrm{O}} 15.3947^{\prime} \\
\mathrm{E}^{\mathrm{O}} 07.1488^{\prime}\end{array}$ & $22^{\circ} \mathrm{C}$ \\
\hline $\begin{array}{c}\text { River Onyami Water } \\
\text { Sample } 2\end{array}$ & Site 6 & $\begin{array}{l}\mathrm{N}^{\mathrm{O}} 15.3935^{\prime} \\
\mathrm{E}^{\mathrm{O}} 06.1421\end{array}$ & $21^{\circ} \mathrm{C}$ \\
\hline $\begin{array}{c}\text { River Onyami Water } \\
\text { Sample } 3 \\
\end{array}$ & Site 7 & $\begin{array}{l}\mathrm{N}^{\mathrm{O}} 15.3898^{\prime} \\
\mathrm{E}^{\mathrm{O}} 06.1396^{\prime}\end{array}$ & $25^{\circ} \mathrm{C}$ \\
\hline $\begin{array}{c}\text { River Onyami Water } \\
\text { Sample } 4\end{array}$ & Site 8 & $\begin{array}{l}\mathrm{N}^{\circ} 15.3948^{\prime} \\
\mathrm{E}^{\mathrm{O}} 06.1492\end{array}$ & $29^{\circ} \mathrm{C}$ \\
\hline
\end{tabular}

\subsection{Sampling Procedure: Sample Collection, Preparation and Sampling Design}

\subsubsection{Soil Sample Collection and Preparation}

Soil samples were collected by dividing each quarry into four quadrants. The soil samples were randomly collected at various distances using the Dutch soil auger assisted with a hand trowel within each sampling point at $0-15 \mathrm{~cm}$ depth. The soil samples from each of the quarry were homogenized in a clean plastic bucket and a composite sample was drawn from each of them. This process was done for all the three quarry soil samples (Fakunle, Chestedi and F.A.U.C. Golden Ltd). All the composite samples were air dried and sorted to remove plant materials and pebbles. They were later grounded with agate mortar into size, enough to pass through a $2 \mathrm{~mm}$ sieve, which were then poured into polythene bags and labelled adequately for analyses.

\subsubsection{Water Samples Collection and Preparation}

Water samples were collected from the River Onyami around the quarry at different sampling sites of 5 meters apart: Site 5, Site 6, Site 7 and Site 8 using a one litre plastic container. Prior to the collection of the water sample from the stream, the containers were washed with detergent, rinsed with water to eliminate the detergent and soaked overnight with chromic acid to ensure proper and 
complete removal of impurities and contaminants. The plastic containers were properly rinsed again with distilled water and rinsed three times with the stream water sample before filling it with the water samples. The actual samplings were done midstream by dipping each sample bottle at approximately $20 \mathrm{~cm}$ below the water surface, projecting the mouth of the container against the direction of flow of the river water. After the samples were collected, $2 \mathrm{~mL}$ of concentrated nitric acid $\left(\mathrm{HNO}_{3}\right)$ was dissolved in each one litre container of the stream water, as a preservative for the metal ions. After collection, the samples were protected from direct sunlight and transported in a cooler box containing ice packs to the laboratory for analyses. All samples were stored at $4^{\circ} \mathrm{C}$ and analyzed within 48 hours of sample collection.

Permissible limits/contamination levels for the available elements in the soil and water samples after analysis were compared with the World Health Organisation (WHO) standard, European Regulatory Standard Maximum Contamination Limits (EURS), United States Environmental Protection Agencies (USEPA), Canadian Council of Ministers of Environment (CCME) and Department of Petroleum Resources Nigeria (DPR) standards, in order to ascertain their level of toxicity in the environment.

\subsubsection{Method of Analysis for the Quarry Soil Samples $p H$}

Twenty (20) grams of the soil aggregate was weighed into a $50 \mathrm{~mL}$ beaker and $20 \mathrm{~mL}$ of distilled water was added. The soil/water mixture (ratio 1:1) was allowed to stand for 30mins and stirred occasionally with a glass rod. The $\mathrm{pH}$ was measured using a digital $\mathrm{pH}$ meter (Jenway $3020 \mathrm{pH}$ meter). The $\mathrm{pH}$ meter was calibrated using buffer 4 and 7. The electrodes were rinsed and subsequently immersed into the soil/water mixture, and the $\mathrm{pH}$ was recorded (Black, 1965).

\subsubsection{Particle size analysis - Hydrometer method}

Fifty (50) grams of soil sample was weighed into a $250 \mathrm{~mL}$ beaker and $100 \mathrm{~mL}$ of distilled water and $10 \mathrm{~mL}$ of concentrated $\mathrm{H} 2 \mathrm{O} 2$ were added to the soil. The content of the beaker was heated until frothing stopped. The mixture was cooled and transferred into shaking bottles. $20 \mathrm{~mL}$ of sodium hexametaphosphate solution was added and the mixture shaken for 1 hour. The suspension was transferred to $1 \mathrm{~L}$ sedimentation cylinder and brought to mark with water. A plunger was used to agitate the suspension. The hydrometer was then lowered into the suspension and its reading was taken after 40 seconds. The temperature was noted. The first reading, R1, gave the percent clay and silt. The suspension was allowed to stand for 2 hours before the hydrometer reading was taken again. The second reading R2, gave the percent clay (Bouyoucos, 1962).

\subsubsection{Exchangeable}

Five (5) grams of air dried soil was weighed into a $150 \mathrm{~mL}$ plastic bottle and $50 \mathrm{~mL}$ of the $1 \mathrm{MKCl}$ was added and then shaken mechanically for 1 hour. It was filtered using a Whatman No. 1 filter paper into a $25 \mathrm{~mL}$ conical flask, 3 drops of phenolphthalein indicator $(0.1 \mathrm{~g}$ of the dry indicator in $100 \mathrm{~mL}$ of $95 \%$ ethanol) were added into the conical flask and then titrate against the $0.05 \mathrm{M} \mathrm{NaOH}$ until the colourless solution turned to pink (Loganaet al., 1985).

\subsubsection{Cation Exchange Capacity (C.E.C)}

Five (5) grams of soil sample was weighed into a $250 \mathrm{~mL}$ polypropylene bottle and $100 \mathrm{~mL}$ of $1 \mathrm{M}$ NH4OAc solution was added and stoppered. The mixture was shaken for 30mins in a mechanical shaker (Heldoph) at 200rpm for 30mins. The supernatant was filtered through Whatman No. 1 filter paper. The concentration of $\mathrm{K}+$ and $\mathrm{Na}+$ in the extract were determined by Flame photometer while $\mathrm{Mg} 2+$ and $\mathrm{Ca} 2+$ were determined using Atomic Absorption Spectrophotometer (Buck Scientific VGP 210 model). The equipment was calibrated using various concentrations of the metals ranging from $2-20 \mathrm{ppm}$ prepared from analytical grade reagents (Sigma, BDH and Buck Scientific). The summation of the various cations was reported as cation exchange capacity (Black, 1965).

\subsubsection{Phosphorus}

Five (5) grams of the soil was weighed into a polypropylene bottle and $40 \mathrm{~mL}$ of the extracting solution $\left(0.03 \mathrm{M} \mathrm{NH}_{4} \mathrm{~F}\right.$ in $\left.0.025 \mathrm{M} \mathrm{HCl}\right)$ was added and stoppered. The mixture was shaken manually for 1 minute and filtered with Whatman filter paper No. 1. The clear supernatant was kept for phosphorus determination. 
The concentration of phosphorus in the extract was determined by volumetric method. $5 \mathrm{~mL}$ of the filtrate or supernatant was pipette into a $50 \mathrm{~mL}$ conical flask and the $\mathrm{pH}$ adjusted to 5 by adding 3 drops of p-nitrophenol and some drops of $2 \mathrm{M} \mathrm{NH}_{4} \mathrm{OH}$ until a yellow colour was obtained. $30 \mathrm{~mL}$ of water was then added followed by $10 \mathrm{~mL}$ of ascorbic acid reagent. The solution was then made up to $100 \mathrm{mLmark}$ with distilled water and the absorbance was read in a spectrophotometer at $660 \mathrm{~nm}$ (Bray and Kurtz, 1965)

\subsubsection{Nitrogen}

$0.2 \mathrm{~g}$ of finely grounded soil was weighed into $100 \mathrm{~mL}$ Kjeldahl digestion flask. One tablet of selenium catalyst and $4 \mathrm{~mL}$ of concentrated $\mathrm{H}_{2} \mathrm{SO}_{4}$ were added to the flask and was shaken to ensure complete mixing of the soil and the catalyst mixture. The flask was placed on the micro Kjeldahl heater and digested for about 45 minutes. At the completion of the digestion, the mixture was found to be clear. The mixture was cooled until it is just warm to touch and $10 \mathrm{~mL}$ distilled water was added and the mixture filtered through a Whatman No. 1 filter paper into a $100 \mathrm{~mL}$ volumetric flask. The flask was further rinsed with distilled water and the filtrate made up to mark. The concentration of nitrogen in the filtrate was determined by colorimetric method. $5 \mathrm{~mL}$ of the filtrate was pipetted into a $25 \mathrm{~mL}$ volumetric flask. $2.5 \mathrm{~mL}$ of alkaline phenol, $1 \mathrm{~mL}$ of sodium potassium tartrate and $2.5 \mathrm{~mL}$ of sodium hypochlorite were added and shook well and made up to mark with distilled water. The sample was then read colorimetrically at $630 \mathrm{~nm}$. Nitrogen standard (1000ppm) was prepared by dissolving $4.7 \mathrm{~g}$ of the dried ammonium sulphate in 1L volumetric flask with distilled water and made up to volume. From 1000ppm nitrogen stock solution, 100ppm nitrogen was prepared, which was used in preparing $5,10,15$ and $25 \mathrm{ppm}$ nitrogen standards. To each of the standard, $4 \mathrm{~mL}$ of $\mathrm{H}_{2} \mathrm{SO}_{4}$ and $0.95 \mathrm{~g}$ of anhydrous sodium sulphate were added and standard were given same treatments as sample above, before making up to $100 \mathrm{~mL}$. A blank solution was prepared without nitrogen but having the same quantity of acid and anhydrous sodium sulphate (Vogel, 2008).

\subsubsection{Organic Carbon}

$5 \mathrm{~mL}$ of $\mathrm{K}_{2} \mathrm{Cr}_{2} \mathrm{O}_{7}$ solution was added to $1 \mathrm{~g}$ of soil sample in a $250 \mathrm{~mL}$ conical flask and swirled gently to wet the sample thoroughly. $20 \mathrm{~mL}$ of concentrated $\mathrm{H}_{2} \mathrm{SO}_{4}$ was then added and the mixture was allowed to cool. $10 \mathrm{~mL}$ of distilled water was added followed by $5 \mathrm{~mL}$ of phosphoric acid and then $8-$ 10 drops of diphenylamine indicator were added to the mixture and was then titrated against $0.5 \mathrm{M}$ iron (II) sulphate solution to a green endpoint. A blank determination was also performed. The blank contained $50 \mathrm{~mL}$ of the $\mathrm{K}_{2} \mathrm{Cr}_{2} \mathrm{O}_{7}$ solution, $20 \mathrm{~mL}$ concentrated $\mathrm{H}_{2} \mathrm{SO}_{4}, 100 \mathrm{~mL}$ distilled water and 5 drops of Ferroin indicator (Walkey and Black, 1934).

\subsection{Sequential Extraction Procedure (Sep)}

The procedure of Tessier et al., (1979) was used for this study. In this method, heavy metals are separated into five operational defined fractions.1g of soil sample was used for the sequential extraction. After successive extraction process, centrifuging the mixture at $1500 \mathrm{rpm}$ for $15 \mathrm{mins}$ effected the liquid-solid phase separation. The supernatant was decantated into a polypropylene bottle for metal analysis while the residue was carried through the whole extraction process. Five step extraction schemes was chosen for this study which defines a variety of geochemical fractions and they include; Exchangeable - F1, Bound to carbonates - F2, Bound to Iron and Manganese - F3, Bound to organic matter - F4 and Residual Fraction - F5

\subsubsection{Fraction F1 - Exchangeable}

This fraction indicates the capacity of the soil to adsorb or desorb heavy metals in relation to changes in the ionic composition of the soil. The sediment was extracted at room temperature for 1 hour with $8 \mathrm{~mL}$ of either magnesium chloride solution $(1 \mathrm{M} \mathrm{MgCl}, \mathrm{pH} 7.0)$ or sodium acetate solution (1M $\mathrm{NaOAc}, \mathrm{pH} 8.2$ ) with continuous agitation.

\subsubsection{Fraction F2 - Metals Bound to Carbonate}

The residue from fraction 1 (F1) was leached at room temperature with $8 \mathrm{~mL}$ of $1 \mathrm{M}$ sodium acetate $(\mathrm{NaOAc})$ and adjusted to $\mathrm{pH} 5.0$ with acetic acid (HOAc). Continuous agitation was maintained and the time necessary for complete extraction was evaluated. 
Baseline Levels of the Chemical Parameters in the Vicinity of Quarry Industries in Igarra, Akoko Edo Local Government, Edo State

\subsubsection{Fraction F3 - Metals Bound to Fe-Mn Oxides}

The residue from fraction 2 (F2) was extracted with $20 \mathrm{~mL}$ of either $0.3 \mathrm{M} \mathrm{Na} \mathrm{S}_{2} \mathrm{~S}_{2}+0.175 \mathrm{M}$ Nacitrate $+0.025 \mathrm{M} \mathrm{H}$-citrate, or $0.04 \mathrm{M} \mathrm{NH}_{2} \mathrm{OH} . \mathrm{HCl}$ in $25 \%$ (v/v) $\mathrm{HOAc}$. The latter experiments were performed at $96^{\circ} \mathrm{C}$ with occasional agitation and the time needed for complete dissolution of the free iron oxides was evaluated.

\subsubsection{Fraction F4-Metals Bound to Organic Matter}

To the residue from fraction 3 (F3) were added $3 \mathrm{~mL}$ of $0.02 \mathrm{M} \mathrm{HNO} \mathrm{HN}_{3}$ and $5 \mathrm{~mL}$ of $30 \% \mathrm{H}_{2} \mathrm{O}_{2}$ adjusted to $\mathrm{pH} 2$ with $\mathrm{HNO}_{3}$, and the mixture was heated to $85^{\circ} \mathrm{C}$ for 2 hours with occasional agitation. A second 3-mL aliquot of $30 \% \mathrm{H}_{2} \mathrm{O}_{2}\left(\mathrm{pH} 2\right.$ with $\mathrm{HNO}_{3}$ ) was then added and the sample was heated again to $85^{\circ} \mathrm{C}$ for 3 hours with intermittent agitation. After cooling, $5 \mathrm{~mL}$ of $3.2 \mathrm{M} \mathrm{NH}_{4} \mathrm{OAc}$ in $20 \%$ (v/v) $\mathrm{HNO}_{3}$ was added and the sample was diluted to $20 \mathrm{~mL}$ and agitated continuously for $30 \mathrm{~min}$. The addition of $\mathrm{NH}_{4} \mathrm{OAc}$ is designed to prevent adsorption of extracted metals onto the oxidized sediment.

\subsubsection{Fraction F5 - Residual Metals}

The residue from fraction $4(\mathrm{~F} 4)$ was digested with a $\mathrm{HF}-\mathrm{HClO} 4$ mixture according to the procedure described below for total metal analysis. The "selective" extractions were conducted in centrifuge tubes (polypropylene, 50mL) to minimize losses of solid material. Between each successive extraction, separation was effected by centrifuging at $10000 \mathrm{rpm}$ for $30 \mathrm{~min}$. The supernatant was removed with a pipette and analyzed for trace metals, whereas the residue was washed with $8 \mathrm{~mL}$ of deionized water; after centrifugation for $30 \mathrm{~min}$, this second supernatant was discarded.

\section{RESULT AND DISCUSSION}

\subsection{Physico-Chemical Properties of the Quarry Soils and Water}

The results obtained from the physico-chemical analysis of Chestedi, F.A.U.C Golden Ltd and Fakunle quarry soil samples, labeled as Site 1, Site 2 and Site 3 respectively are shown in table 3 below:

Table3. The physico-chemical properties of the quarry soils samples

\begin{tabular}{|c|c|c|c|c|}
\hline PARAMETERS & UNITS & CHESTEDI & F.A.U.C & FANKULE \\
\hline $\mathbf{p H}$ & & Site 1 & Site 2 & Site 3 \\
\hline $\mathbf{E C}$ & & 6.5 & 6.7 & 7.2 \\
\hline $\mathbf{C a}$ & $\mu \mathrm{S} / \mathrm{cm}$ & 226 & 263 & 304 \\
\hline $\mathbf{M g}$ & $\mathrm{mg} / \mathrm{kg}$ & 147.4 & 138.6 & 160.9 \\
\hline $\mathbf{N a}$ & $\mathrm{mg} / \mathrm{kg}$ & 106.2 & 98.18 & 125.7 \\
\hline $\mathbf{K}$ & $\mathrm{mg} / \mathrm{kg}$ & 45.2 & 52.6 & 60.8 \\
\hline $\mathbf{P O}_{\mathbf{4}}$ & $\mathrm{mg} / \mathrm{kg}$ & 58.76 & 68.38 & 79.04 \\
\hline $\mathbf{S O}_{\mathbf{4}}$ & $\mathrm{mg} / \mathrm{kg}$ & 5.73 & 7.44 & 3.62 \\
\hline $\mathbf{C L}$ & $\mathrm{mg} / \mathrm{kg}$ & 12.9 & 16.13 & 11.42 \\
\hline $\mathbf{A l k a l i n i t y}$ & $\mathrm{mg} / \mathrm{kg}$ & 158.2 & 133.8 & 146.5 \\
\hline $\mathbf{N H}-\mathbf{N}$ & $\mathrm{mg} / \mathrm{kg}$ & 106 & 97.4 & 118.3 \\
\hline $\mathbf{E A}$ & $\mathrm{mg} / \mathrm{kg}$ & 7.46 & 13.67 & 9.31 \\
\hline $\mathbf{C E C}$ & $\mathrm{mg} / \mathrm{kg}$ & 98.65 & 110.4 & 103.14 \\
\hline TOC & $\mathrm{mg} / \mathrm{kg}$ & 357.56 & 357.76 & 426.44 \\
\hline Clay & $\%$ & 0.63 & 0.47 & 0.41 \\
\hline Silt & $\%$ & 6.21 & 8.22 & 6.18 \\
\hline Sand & $\%$ & 3.61 & 4.3 & 6.7 \\
\hline POM & $\%$ & 90.18 & 87.48 & 87.12 \\
\hline
\end{tabular}

Note: POM - Particulate organic matter

The soil physico-chemical analysis according to table 3.1 shows that the $\mathrm{pH}$ values of the soil samples ranges from $6.5-7.2 \mathrm{pH}$ units. This shows that all the $\mathrm{pH}$ values are slightly acidic/neutral. It is a fact that $\mathrm{pH}$ is an important soil property, having great effects on solute concentration and sorption/desorption of contaminant in soil (Kademet al., 2004). High pH might reduce the mobility of some metal species down the soil strata while low $\mathrm{pH}$ values usually enhance metal distribution and 
transport in soil. The closeness of the $\mathrm{pH}$ values obtained for the soils may suggest that the effect of $\mathrm{pH}$ on the availability of the metals is minimal. Soil $\mathrm{pH}$ or soil reaction is an indication of the acidity or alkalinity of the soil and it is measured in $\mathrm{pH}$ units. Soil $\mathrm{pH}$ is the negative logarithm of the hydrogen ion concentration or nutrients. Most mineral and nutrients are more soluble or available in acidic soils than in neutral or slightly alkaline soils. Soils tend to become acidic as a result of rain water leaching away basic ions $\left(\mathrm{Ca}^{2+}, \mathrm{Mg}^{2+}, \mathrm{K}^{+}\right.$and $\left.\mathrm{Na}^{+}\right)$(Bickelhaupt, 2015).

Alkaline soil (mostly clay soils) with a high $\mathrm{pH}(>9)$ have poor soil structure and a low infiltration capacity. They are not saline, i.e. the total amount of soluble soils especially sodium chlorides, is not excessive. Often, they have a hard-calcareous layer at 0.5 to $1 \mathrm{~m}$ depth (Oosterbaan, 2003). Alkalinity concentration in the soil samples ranges from $97.4 \mathrm{mg} / \mathrm{kg}-118.3 \mathrm{mg} / \mathrm{kg}$ which is very low, and it is as a result of the $\mathrm{pH}$ of the soil being less than $9 \mathrm{pH}$ units.

The particle size of the quarry soil samples shows that the quantity of sand ranges from $87.12 \%$ $90.18 \%$ and which is the predominant fraction, the quantity of silt ranges from $3.61 \%-6.70 \%$, while the quantity of clay ranges from $6.31 \%-8.22 \%$. Thus, all soil examined showed less than $10 \%$ of silt and clay, and it contains a very high percentage of sand (80\% and above). Therefore, soils with high sand content exceeding $70 \%$ have weak surface aggregation (Donahue et al., 1990) and such soils are porous and have high rate of water infiltration and air circulation (Gbadegesin and Abua, 2011).

Values of Electrical Conductivity (EC) ranges from $226 \mu \mathrm{S} / \mathrm{cm}$ to $304 \mu \mathrm{S} / \mathrm{cm}$, which are relatively high for the three quarry soil samples and they exceed the critical values of $2 \mu \mathrm{S} / \mathrm{cm}(\mathrm{FAO}, 1994)$ for sensitive crop species and $4 \mu \mathrm{S} / \mathrm{cm}$ (Donahue et al., 1994) for identifying the soils as saline soils. Thus, the soil samples of Site 1, Site 2 and Site 3 are very high in electrical conductivity and therefore saline. Therefore, high electrical conductivity can cause water stress, nutrient imbalance and affects nutrient uptake by soils (Agronomic Spotlight, 2015).

The cation exchange capacity (C.E.C) of the soils was observed to range from $357.56 \mathrm{mg} / \mathrm{kg}-$ $426.44 \mathrm{mg} / \mathrm{kg}$, which indicates the amount of metal cations such as $\mathrm{Ca}^{2+}, \mathrm{Mg}^{2+}, \mathrm{Na}^{+}$and $\mathrm{K}^{+}$that are available in the soil, resulting from the porous nature and $\mathrm{pH}$ of the soil. The soil samples from the three quarries shows a low C.E.C which indicates that Soils with low CEC are more likely to develop deficiencies in potassium $\left(\mathrm{K}^{+}\right)$, magnesium $\left(\mathrm{Mg}^{2+}\right)$ and other cations, while high CEC soils are less susceptible to leaching of these cations (CUCE, 2007). The addition of organic matter will increase the CEC of a soil but will require time to take effect. The organic content of the sandy fraction of the soil is very low hence low CEC. Therefore, exchangeable bases are generally high in the soil. The CEC is directly related to the capacity of adsorbing heavy metals since the adsorption behaviour depends on combination of the soil properties and the specific characteristics of the element (Barry et al., 1995).

Exchangeable acidity (EA) of the quarry soils samples ranges $98.65 \mathrm{mg} / \mathrm{kg}-110.4 \mathrm{mg} / \mathrm{kg}$ and it indicates the total amount of C.E.C as $\mathrm{H}^{+}$and $\mathrm{Al}^{3+}$ occupied by the acidic cations. The Exchangeable acidity is one-fifth of the amount of C.E.C that one-fifth of the exchange sites in the soil are occupied by acidic hydrogen and aluminum ions. The remaining four-fifth part will be occupied by basic cations. Therefore, the E.A. for each quarry compared to their various C.E.C is very low, therefore, the relatively lower the exchangeable acidity of the soil (Clemson Public Service Activities, 2015).

Particulate Organic Matter ranges from $0.68 \%-0.97 \%$ and which is very low $(<3 \%)$. Particulate Organic Matter (POM) plays a major role in determining soil physical characteristics. Soil with high particulate organic matter levels would generally be expected to have good structure, moisture retention and water infiltration (Spargo et al., 2013).

Total organic carbon (TOC) is the carbon (C) stored in soil organic matter (SOM). Organic carbon (OC) enters the soil through the decomposition of plant and animal residues, root exudates, living and dead microorganisms, and soil biota. The total organic carbon TOC ranges from $0.41 \%-0.49 \%$ for the quarry soil samples.

Results from the soil analysis shows that the concentration of calcium ranges from $138.60 \mathrm{mg} / \mathrm{kg}$ $160.90 \mathrm{mg} / \mathrm{kg}$. The concentration of calcium in the soil samples has higher value than $80 \mathrm{mg} / \mathrm{kg}$ as recommended by Adulaji and Ekong (1981) as the critical limit for calcium concentration in soils. 
The concentration of magnesium ranges from $98.18 \mathrm{mg} / \mathrm{kg}-125.70 \mathrm{mg} / \mathrm{kg}$ in all the quarry soil samples. The range of concentration for magnesium in the quarry soil samples is far greater than the critical value of $15 \mathrm{mg} / \mathrm{kg}$ as suggested by Akande and Awojobi (2003). It is however noticed that there is higher concentration of the said nutrient in the topsoil.

The values of the concentration of potassium in the soil samples ranges from $58.76 \mathrm{mg} / \mathrm{kg}$ $79.04 \mathrm{mg} / \mathrm{kg}$. And it is close to and less than the acceptable limit of $58.50 \mathrm{mg} / \mathrm{kg}$ suggested by Sobulo and Osiname (1981).

The concentration range of sodium from the soil analysis results is $45.20 \mathrm{mg} / \mathrm{kg}-60.80 \mathrm{mg} / \mathrm{kg}$. These result could be seen to havefallen below the required sodium permissible limit of $80 \mathrm{mg} / \mathrm{k}$ gas suggested by Tisade and Werner (1985).

The concentration of phosphate in the three quarry soil samples ranges from $3.62 \mathrm{mg} / \mathrm{kg}-7.44 \mathrm{mg} / \mathrm{kg}$, which is higher than the permissible limit of $0.40 \mathrm{mg} / \mathrm{kg}$ (WHO, 1983; Ministry of Agriculture, Fisheries and Food, 1987). The concentration of sulphate in the three quarry soil samplesranges from $11.42 \mathrm{mg} / \mathrm{kg}-16.13 \mathrm{mg} / \mathrm{kg}$ and whichdoes not

exceed the WHO (1983) and Ministry of Agriculture, Fisheries and Food, London (1987) permissible limits of $200.00 \mathrm{mg} / \mathrm{kg}$.

The concentration of chloride ion was observed to range from $133.80 \mathrm{mg} / \mathrm{kg}-158.20 \mathrm{mg} / \mathrm{kg}$, though not above the permissible limits of $250 \mathrm{mg} / \mathrm{kg}$ (WHO, 1983). Common soluble salts present in the environment include chlorides and sulphates of calcium, magnesium, sodium and potassium. Salt contamination is not normally a hazard to human health; however, it can cause adverse and long lasting environmental impacts to soil and ground water resources because chloride is highly soluble, it does not adsorb onto soil particles, it does not degrade, and generally, it inhibits biological processes. Releases of salt onto the ground can damage soils by destroying the soil structure and permeability. The presence of high concentrations of soluble salts can inhibit seed germination and a plant's ability to uptake water. Salt-contaminated soil in the near surface can lose its ability to support agricultural crops, native grasses, or other vegetation if salt levels are high enough and potentially contributing to surface erosion (BER, 2004).

Table4. The concentration of heavy metals presents in the operationally defined area (Site 1, Quarry soil)

\begin{tabular}{|c|c|c|c|c|c|c|c|}
\hline Metals & Units & Exchangeable & $\begin{array}{c}\text { Bound to } \\
\text { Carbonates }\end{array}$ & $\begin{array}{c}\text { Bound to } \\
\text { Fe-Mn } \\
\text { Oxides }\end{array}$ & $\begin{array}{c}\text { Bound to } \\
\text { Organic } \\
\text { Matter }\end{array}$ & Residual & Total Conc. \\
\hline $\mathbf{F e}$ & $\mathrm{mg} / \mathrm{kg}$ & 0.04 & 0.80 & 172.0 & 11.40 & 91.75 & $\mathbf{2 7 5 . 9 9}$ \\
\hline $\mathbf{Z n}$ & $\mathrm{mg} / \mathrm{kg}$ & 10.54 & 1.85 & 64.33 & 2.11 & 18.06 & $\mathbf{9 6 . 8 9}$ \\
\hline $\mathbf{C u}$ & $\mathrm{mg} / \mathrm{kg}$ & 3.40 & 1.11 & 43.24 & 0.92 & 13.89 & $\mathbf{6 2 . 5 6}$ \\
\hline $\mathbf{M n}$ & $\mathrm{mg} / \mathrm{kg}$ & 0.05 & 0.82 & 123.34 & 0.32 & 27.60 & $\mathbf{1 5 2 . 1 3}$ \\
\hline $\mathbf{P b}$ & $\mathrm{mg} / \mathrm{kg}$ & 0.23 & 3.12 & 3.08 & 0.074 & 56.60 & $\mathbf{6 3 . 1 0 4}$ \\
\hline $\mathbf{C r}$ & $\mathrm{mg} / \mathrm{kg}$ & 0.14 & 0.58 & 3.04 & 0.03 & 13.88 & $\mathbf{1 7 . 6 7}$ \\
\hline
\end{tabular}

The concentration of $\mathrm{NH}_{4}-\mathrm{N}$ in Site 1 is $7.46 \mathrm{mg} / \mathrm{kg}$, Site 2 is $13.67 \mathrm{mg} / \mathrm{kg}$ and Site 3 is $9.31 \mathrm{mg} / \mathrm{kg}$ and it does not exceed the WHO (1983) and Ministry of Agriculture, Fisheries and Food, London (1987) permissible limits of $10-50 \mathrm{mg} / \mathrm{kg}$.Fractionation and Distribution of Heavy Metals in the soil samples

From Table 4 - the total metal concentration in this site follows the order of $\mathrm{Fe}>\mathrm{Mn}>\mathrm{Zn}>\mathrm{Pb}>\mathrm{Cu}>\mathrm{Cr}$. $\mathrm{Fe}, \mathrm{Zn}, \mathrm{Cu}$ and $\mathrm{Mn}$ were found to be dominant in the Fe-Mn oxide reducible fractions compared to the other labile fractions. This could be due to the fact that Fe and Mn oxides constitute a significant sink for heavy metals in aquatic system under oxidizing conditions as explained by Gibbs et al., (1997).

The higher concentration of elements such as $\mathrm{Fe}, \mathrm{Zn}, \mathrm{Cu}$ and $\mathrm{Mn}$ associated with this fraction are adsorbed to the Fe-Mn colloids and they are thermodynamically unstable under anoxic conditions (Jenne, 1968), illustrating the ability of Fe-Mn oxides to scavenge trace metals from solution through processes such as adsorption and co-precipitation (Lim and Kiu, 1995). Site-to-site variations in the concentration of metals in this fraction may be attributable to the fact that the mechanisms of their adsorption and co-precipitation are sensitive to changes in redox potential, rendering them moderately mobile and affecting their relative concentration. This fraction thus carries a significant burden of metals, making substantial quantities potentially available to biota with changes in environmental conditions. While $\mathrm{Pb}$ and $\mathrm{Cr}$ are highest in concentration at the residual phase. 
Baseline Levels of the Chemical Parameters in the Vicinity of Quarry Industries in Igarra, Akoko Edo Local Government, Edo State

Heavy metals bound to the residual fractions is considered as the most stable, less reactive and less available since it is occluded within the crystal lattice layer of the silicates and well crystallized oxide (Terus, 1995).

The total heavy metal concentrations in this site from Table 5, follows the order of $\mathrm{Fe}>\mathrm{Zn}>\mathrm{Cu}>\mathrm{Mn}>\mathrm{Pb}>\mathrm{Cr}$. The total concentration (Exchangeable + Bound to carbonate + Bound to Iron and Manganese oxide + Bound to organic matter + Residual) of the heavy metals in this analysis is the sum of all the concentrations in each fraction.

$\mathrm{Fe}, \mathrm{Zn}$ and $\mathrm{Cu}$ are highest in concentration at the bound to $\mathrm{Fe}-\mathrm{Mn}$ oxides reducible phase. The organic and Fe-Mn Oxide fraction could be considered relatively stable, slowly mobile and poorly available but could change with variations in redox conditions (Horsfall and Spiff, 2005).The concentration of zinc in this fraction is high enough to pose serious environmental problem to the underground water (Wangbojeet al., 2014).

Table5. The concentration of heavy metals presents in the operationally defined area (Site 2, Quarry soil)

\begin{tabular}{|c|c|c|c|c|c|c|c|}
\hline Metals & Units & Exchangeable & $\begin{array}{c}\text { Bound to } \\
\text { Carbonates }\end{array}$ & $\begin{array}{c}\text { Bound to } \\
\text { Fe-Mn } \\
\text { Oxides }\end{array}$ & $\begin{array}{c}\text { Bound to } \\
\text { Organic } \\
\text { Matter }\end{array}$ & Residual & $\begin{array}{c}\text { Total } \\
\text { Conc. }\end{array}$ \\
\hline $\mathbf{F e}$ & $\mathrm{mg} / \mathrm{kg}$ & 0.10 & 2.80 & 224.00 & 14.00 & 81.25 & $\mathbf{3 2 2 . 1 5}$ \\
\hline $\mathbf{Z n}$ & $\mathrm{mg} / \mathrm{kg}$ & 5.92 & 2.01 & 98.21 & 0.51 & 22.01 & $\mathbf{1 2 8 . 6 6}$ \\
\hline $\mathbf{C u}$ & $\mathrm{mg} / \mathrm{kg}$ & 7.20 & 2.04 & 62.32 & 1.02 & 9.58 & $\mathbf{8 2 . 1 6}$ \\
\hline $\mathbf{M n}$ & $\mathrm{mg} / \mathrm{kg}$ & 0.12 & 8.72 & 91.04 & 0.04 & 7.70 & $\mathbf{1 0 7 . 6 2}$ \\
\hline $\mathbf{P b}$ & $\mathrm{mg} / \mathrm{kg}$ & 0.02 & 2.03 & 6.89 & 0.20 & 7.61 & $\mathbf{1 6 . 7 5}$ \\
\hline $\mathbf{C r}$ & $\mathrm{mg} / \mathrm{kg}$ & 0.26 & 0.86 & 0.76 & 0.01 & 9.38 & $\mathbf{1 1 . 2 7}$ \\
\hline
\end{tabular}

$\mathrm{Mn}$ is highest at the organic matter fraction. considerable amounts of trace metals are retained in this fraction, which is less mobile, since it is thought to be associated with higher molecular weight, stable and humic which release small amount of metal gradually (Zhang, 1989).

While $\mathrm{Pb}$ and $\mathrm{Cr}$ are highest in the residual fractions. The residual fraction is considered the most stable, less reactive and less bioavailable since it is occluded within the crystal lattice layer of silicates and well crystallized oxide minerals (Segarra et al., 2008).

The total heavy metal concentrations in this site from Table 3.5, follows the order of $\mathrm{Fe}>\mathrm{Zn}>\mathrm{Mn}>$ $\mathrm{Cu}>\mathrm{Pb}>\mathrm{Cr}$.

$\mathrm{Fe}, \mathrm{Zn}, \mathrm{Cu}$ and $\mathrm{Mn}$ are highest in concentrations in the $\mathrm{Fe}-\mathrm{Mn}$ oxide reducible fractions While $\mathrm{Pb}$ and $\mathrm{Cr}$ are highest in concentration at the residual fractions.

Table6. The concentration of heavy metals presents in the operationally defined area (Site 3, Quarry soil)

\begin{tabular}{|c|c|c|c|c|c|c|c|}
\hline Metals & Units & Exchangeable & $\begin{array}{c}\text { Bound to } \\
\text { Carbonates }\end{array}$ & $\begin{array}{c}\text { Bound to } \\
\text { Fe-Mn } \\
\text { Oxides }\end{array}$ & $\begin{array}{c}\text { Bound to } \\
\text { Organic } \\
\text { Matter }\end{array}$ & Residual & $\begin{array}{c}\text { Total } \\
\text { Conc. }\end{array}$ \\
\hline $\mathbf{F e}$ & $\mathrm{mg} / \mathrm{kg}$ & 0.05 & 2.20 & 154.80 & 10.60 & 72.00 & $\mathbf{2 3 9 . 6 5}$ \\
\hline $\mathbf{Z n}$ & $\mathrm{mg} / \mathrm{kg}$ & 11.21 & 0.98 & 60.10 & 3.04 & 17.21 & $\mathbf{9 2 . 5 4}$ \\
\hline $\mathbf{C u}$ & $\mathrm{mg} / \mathrm{kg}$ & 1.99 & 2.03 & 37.95 & 0.12 & 10.21 & $\mathbf{5 2 . 3 0}$ \\
\hline $\mathbf{M n}$ & $\mathrm{mg} / \mathrm{kg}$ & 0.08 & 5.78 & 0.35 & 11.20 & 17.33 & $\mathbf{3 4 . 7 4}$ \\
\hline $\mathbf{P b}$ & $\mathrm{mg} / \mathrm{kg}$ & 0.15 & 1.12 & 0.76 & 0.39 & 17.72 & $\mathbf{2 0 . 1 4}$ \\
\hline $\mathbf{C r}$ & $\mathrm{mg} / \mathrm{kg}$ & 0.16 & 0.94 & 4.30 & 0.04 & 9.40 & $\mathbf{1 4 . 8 4}$ \\
\hline
\end{tabular}

\subsection{Mobility Factors of the Heavy Metals in the Quarry Soil Samples}

The mobility of heavy metals in soils may be expressed based on absolute and relative content of the fractions weakly bound to soil components. The relative index of metal mobility was calculated as a mobility factor (MF) based on the below equation:

Mobility Factor $=$

Exchangeable + Bound to Carbonate

Exchangeable + Bound to Carbonates + Bound to Fe -Mn Oxides + Bound to Organic matter + Residual $x 100$

Or Mobility Factor $=\frac{F 1+F 2}{F 1+F 2+F 3+F 4+F 5} \times 100$ 
Baseline Levels of the Chemical Parameters in the Vicinity of Quarry Industries in Igarra, Akoko Edo Local Government, Edo State

A high Mobility Factor value for heavy metals in soil has been interpreted as evidence of relatively high lability and biological availability (Ma and Rao, 1997; Kabala and Singh, 2001). The mobility factors of the heavy metals in the three quarry soils are shown below:

Mobility factors for heavy metals in the three quarry soils

Table7. The relative index of metal mobility (Mobility Factor)

\begin{tabular}{|l|l|l|l|}
\hline & \multicolumn{3}{|l|}{ Mobility Factors for the three quarry soils sample } \\
\hline Metals & Site 1 & Site 2 & Site 3 \\
\hline $\mathbf{F e}$ & $0.04 \%$ & $0.94 \%$ & $0.90 \%$ \\
\hline $\mathbf{Z n}$ & $12.80 \%$ & $13.17 \%$ & $6.16 \%$ \\
\hline $\mathbf{C u}$ & $7.20 \%$ & $7.69 \%$ & $11.25 \%$ \\
\hline $\mathbf{M n}$ & $0.57 \%$ & $16.87 \%$ & $8.21 \%$ \\
\hline $\mathbf{P b}$ & $5.07 \%$ & $6.31 \%$ & $12.24 \%$ \\
\hline $\mathbf{C r}$ & $4.08 \%$ & $7.41 \%$ & $9.94 \%$ \\
\hline
\end{tabular}

However, the result obtained from table 3.11 above shows a low mobility factor within the range of $0.04 \%-16.87 \%$, which indicates a lower biological availability and mobility of heavy metals in the soils of the three quarries.

\subsection{Environmental Risk Factor (ERF)}

The environmental risk factor was used to determine the environmental risk in order to establish potential threat of heavy metals (Saenz et al., 2003). The Environmental Risk Factor (ERF) was calculated using the formula;

$\mathbf{E R F}=C S Q V-\frac{C i}{C S Q V} \quad$ or $\mathbf{E R F}=F 5-\frac{F 1+F 2+F 3+F 4}{F 5}$

Where CSQV = Concentration of Sediments Quality Value (heavy metal concentration in residual fraction of sediment which is equivalent to the background/pre-industrial concentration (F5).

$\mathbf{C i}=$ Heavy metal concentration in the first four fractions of sediments $(\mathrm{F} 1+\mathrm{F} 2+\mathrm{F} 3+\mathrm{F} 4)$.

Table8. Environmental Risk factors for heavy metals in the three quarry soils

\begin{tabular}{|c|c|c|c|}
\hline & \multicolumn{3}{|c|}{ ERF for the three quarry soils sample } \\
\hline Metals & ERF for Site 1 & ERF for Site 2 & ERF for Site 3 \\
\hline $\mathbf{F e}$ & 89.74 & 69.67 & 78.29 \\
\hline $\mathbf{Z n}$ & 13.70 & 12.83 & 17.17 \\
\hline $\mathbf{C u}$ & 10.39 & 6.09 & 2.00 \\
\hline $\mathbf{M n}$ & 23.09 & 16.33 & -5.28 \\
\hline $\mathbf{P b}$ & 56.49 & 17.58 & 6.41 \\
\hline $\mathbf{C r}$ & 13.61 & 8.82 & 9.18 \\
\hline
\end{tabular}

Key: $\quad$ ERF $<0=$ Potential Ecological Threat

ERF $>0=$ No Potential Ecological Threat

From the above results, manganese in the Site 3 quarry soil may pose a potential threat to the environment, since its ERF value (-5.28) is negative and less than zero.

\subsection{Contamination Factor}

The contamination factor (CF), according to Lin et al., (2009) was used to determine the level of contamination of the soil by the heavy metals.

The contamination factor was calculated as:

$\mathrm{CF}=\frac{\text { Metal concentration in sediment }}{\text { Background concentration of heavy metals in sediment }}$ or

$\mathrm{CF}=\frac{\mathrm{F} 1+\mathrm{F} 2+\mathrm{F} 3+\mathrm{F} 4}{\mathrm{~F} 5}$

Table9. Contamination factors for heavy metals in the three quarry soil samples

\begin{tabular}{|c|c|c|c|}
\hline & \multicolumn{3}{|c|}{ Contamination Factor for the three quarry soils sample } \\
\hline Metals & CF for Site 1 & CF for Site 2 & CF for Site 3 \\
\hline Fe & 2.01 & 2.33 & 2.97 \\
\hline Zn & 4.35 & 4.38 & 4.85 \\
\hline
\end{tabular}


Baseline Levels of the Chemical Parameters in the Vicinity of Quarry Industries in Igarra, Akoko Edo Local Government, Edo State

\begin{tabular}{|c|c|c|c|}
\hline $\mathbf{C u}$ & 3.50 & 4.12 & 7.58 \\
\hline $\mathbf{M n}$ & 4.51 & 0.98 & 12.98 \\
\hline $\mathbf{P b}$ & 0.12 & 0.14 & 1.20 \\
\hline $\mathbf{C r}$ & 0.28 & 0.58 & 0.20 \\
\hline
\end{tabular}

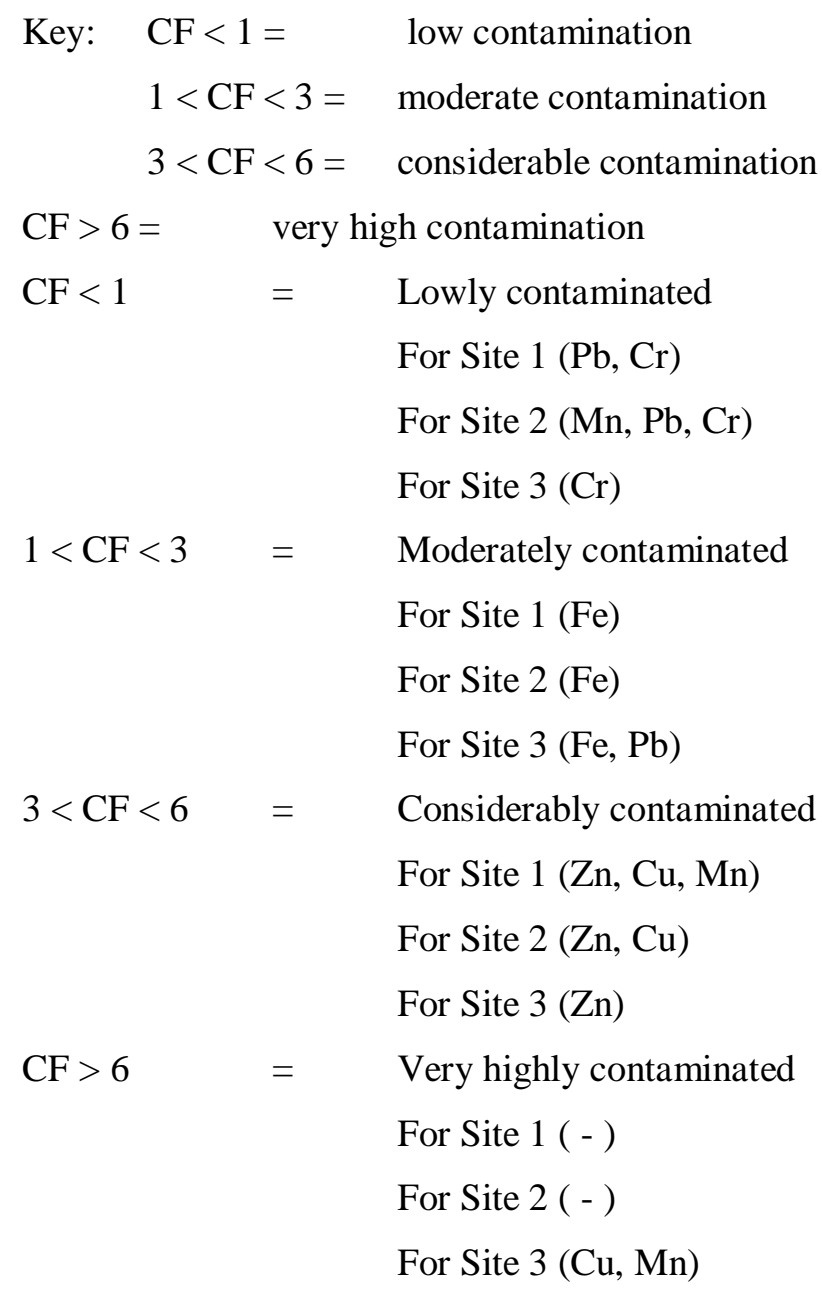

From the above, $\mathrm{Pb}$ and $\mathrm{Cr}$ in (Site 1), $\mathrm{Mn}, \mathrm{Pb}$ and $\mathrm{Cr}$ in (Site 2) and $\mathrm{Cr}$ in (Site 3) has a factor less than unity, which shows that they are very low in contamination with their respective heavy metals listed above. While, the other heavy metals in the quarry soil samples according to the calculation of their contaminated factors, are contaminated.

\subsection{Pollution Load Index}

The pollution load index which was proposed by Tomlinson et al., (1980) was also calculated for comparison of pollution level with heavy metals between the various quarry sites. It was obtained as a contamination factor of each heavy metal with respect to the background value in the soil.

PLI $=\sqrt[n]{\mathrm{Cf} 1 \times \mathrm{Cf} 2 \times \mathrm{Cf} 3 \mathrm{xCf} 4 \ldots \ldots \ldots \ldots \ldots \mathrm{Cfn}}$

Where $\mathrm{n}$ is the total number of heavy metals under investigations, Cf1 is the contamination factor of metal one, Cf2 is the contamination factor of metal two, Cf3 is the contamination factor of metal three and Cfn is the contamination factors of metal n. According Tomlinson et al., (1980), a pollution load index $(\mathrm{PLI})<1$ denote perfection; PLI $=1$ present that only baseline levels of pollutants are present and PLI $>1$ would indicate deterioration of site quality.

Table10. The Pollution Load Index of metals in the three quarries

\begin{tabular}{|c|c|c|}
\hline \multicolumn{3}{|c|}{ Pollution Load Index (PLI) for the three quarry soils sample } \\
\hline PLI for Site 1 & PLI for Site 2 & PLI for Site 3 \\
\hline 1.29 & 7.49 & 16573.70 \\
\hline
\end{tabular}


Baseline Levels of the Chemical Parameters in the Vicinity of Quarry Industries in Igarra, Akoko Edo Local Government, Edo State

The pollution load index values as calculated were all above or greater than 1 . It is high in site 1, slightly higher in site 2 and very high in site 3 . This is an indication that all the sites have metal concentrations which can cause pollution to the environment.

\subsection{Index of Geoaccumulation ( $I_{\text {geo }}$ )}

Index of geoaccumulation $\left(\mathrm{I}_{\mathrm{geo}}\right.$ ) was used to evaluate the heavy metal pollution by comparing current concentrations with reference (control) values (Muller, 1969).

$\mathbf{I}_{\text {geo }}=\log _{2} \frac{C n}{1.5 B n}$

Where $\mathbf{I}_{\text {geo }}$ is Index of geoaccumulationof the metal, $\mathrm{C}_{\mathrm{n}}$ is the measured concentration of the element in the sample and $\mathrm{B}_{\mathrm{n}}$ is the geochemical background value. The constant 1.5 allows us to analyze natural fluctuations in the content of the given substance in the environment as well as very small anthropogenic influences. According to Muller (1969), this index consists of seven scales (0-6) ranging from unpolluted to very highly polluted. The degree of metal pollution in terms of seven enrichment classes

Table10. The Geoaccumulation Index for the three quarry soil samples

\begin{tabular}{|c|c|c|c|}
\hline & \multicolumn{3}{|c|}{ Geoaccumulation Index for the three quarry soils sample } \\
\hline Metals & $\mathbf{I}_{\text {geo }}$ for Site 1 & $\mathbf{I}_{\text {geo }}$ for Site 2 & $\mathbf{I}_{\text {geo }}$ for Site 3 \\
\hline $\mathbf{F e}$ & 1.0039 & 1.15 & 1.40 \\
\hline $\mathbf{Z n}$ & 1.83 & 1.84 & 1.96 \\
\hline $\mathbf{C u}$ & 1.59 & 1.77 & 2.52 \\
\hline $\mathbf{M n}$ & 1.87 & 0.42 & 3.22 \\
\hline $\mathbf{P b}$ & -0.43 & -0.40 & 0.55 \\
\hline $\mathbf{C r}$ & -0.236 & 0.074 & -0.32 \\
\hline
\end{tabular}

The interpretation of the result above was made based on the scale below in comparison with control/refers sample

Table11. The Geo accumulation Index scale

\begin{tabular}{|c|c|c|}
\hline $\mathbf{I}_{\text {geo }}$ Value & I $_{\text {geo }}$ Class & Designation of sediment quality \\
\hline$>5$ & 6 & Extremely contaminated \\
\hline $4-5$ & 5 & Strongly to extremely contaminated \\
\hline $3-4$ & 4 & Strongly contaminated \\
\hline $2-3$ & 3 & Moderately to strongly contaminated \\
\hline $1-2$ & 2 & Moderately contaminated \\
\hline $0-1$ & 1 & Uncontaminated to moderately contaminated \\
\hline $0<$ & 0 & Uncontaminated \\
\hline
\end{tabular}

From the table above,Site 1 is uncontaminated with $\mathrm{Cr}$ and $\mathrm{Pb}$ and moderately contaminated with $\mathrm{Fe}$, $\mathrm{Zn}, \mathrm{Cu}$ and $\mathrm{Mn}$. Site 2 is uncontaminated with $\mathrm{Cr}, \mathrm{Pb}$ and $\mathrm{Mn}$ and moderately contaminated with $\mathrm{Cu}$, $\mathrm{Zn}$ and $\mathrm{Fe}$. Site 3 is uncontaminated with $\mathrm{Cr}$ and $\mathrm{Pb}$, and moderately contaminated with $\mathrm{Fe}$ and $\mathrm{Zn}$, moderately to strongly contaminated with $\mathrm{Cu}$ and strongly contaminated with $\mathrm{Mn}$.

The result of data analysis showed that the $\mathrm{I}_{\text {geo }}$ was distinctively variable and suggests that soils in the quarries ranges from uncontaminated to moderately contaminated with respect to the analyzed heavy metals. $\mathrm{I}_{\text {geo }}$ also revealed that except for site 1 and site 2 soil samples, $\mathrm{Cu}$ and $\mathrm{Mn}$ in site 3 falls in class 3 and 4 respectively (moderately to strongly contaminated and strongly contaminated).

\subsection{Water Analysis}

The results obtained from the physico-chemical analysis of the stream water labelled as Site 5, Site 6, Site 7 and Site 8 respectively are shown in table 3.6 below:

Table12. The physico-chemical properties of the stream water samples

\begin{tabular}{|c|c|c|c|c|c|}
\hline PARAMETERS & UNITS & Site 5 & Site 6 & Site 7 & Site 8 \\
\hline pH & & 6.5 & 7.1 & 6.6 & 6.8 \\
\hline EC & $\mathrm{uS} / \mathrm{cm}$ & 26 & 30 & 22 & 28 \\
\hline TDS & $\mathrm{mg} / \mathrm{l}$ & 13 & 15 & 11 & 14 \\
\hline
\end{tabular}


Baseline Levels of the Chemical Parameters in the Vicinity of Quarry Industries in Igarra, Akoko Edo Local Government, Edo State

\begin{tabular}{|c|c|c|c|c|c|}
\hline TSS & $\mathrm{mg} / \mathrm{l}$ & 0.06 & 0.180 & 0.07 & 0.11 \\
\hline DO & $\mathrm{mg} / \mathrm{l}$ & 8.00 & 7.60 & 2.80 & 6.40 \\
\hline $\mathbf{B O D}$ & $\mathrm{mg} / \mathrm{l}$ & 4.8 & 3.20 & 0.4 & 2.1 \\
\hline $\mathbf{C a}$ & $\mathrm{mg} / \mathrm{l}$ & 3.64 & 4.28 & 2.66 & 3.56 \\
\hline $\mathbf{M g}$ & $\mathrm{mg} / \mathrm{l}$ & 1.78 & 2.16 & 0.78 & 1.21 \\
\hline TOTAL HARDNESS & $\mathrm{mg} / \mathrm{l}$ & 5.40 & 7.10 & 3.60 & 5.73 \\
\hline $\mathbf{P O}_{\mathbf{4}}$ & $\mathrm{mg} / \mathrm{l}$ & 0.08 & 0.13 & 0.10 & 0.06 \\
\hline $\mathbf{S O}_{\mathbf{4}}$ & $\mathrm{mg} / \mathrm{l}$ & 0.32 & 0.40 & 0.39 & 0.33 \\
\hline $\mathbf{N O}_{\mathbf{3}}$ & $\mathrm{mg} / \mathrm{l}$ & 0.68 & 2.70 & 1.77 & 0.52 \\
\hline $\mathbf{N H}_{\mathbf{4}}-\mathbf{N}$ & $\mathrm{mg} / \mathrm{l}$ & 0.13 & 0.15 & 0.07 & 0.12 \\
\hline $\mathbf{N a}$ & $\mathrm{mg} / \mathrm{l}$ & 5.0 & 6.31 & 4.4 & 5.6 \\
\hline $\mathbf{K}$ & $\mathrm{mg} / \mathrm{l}$ & 6.50 & 8.2 & 5.72 & 7.3 \\
\hline Alkalinity & $\mathrm{mg} / \mathrm{l}$ & 19.30 & 30.6 & 23.8 & 15.5 \\
\hline $\mathbf{C h l o r i d e}$ & $\mathrm{mg} / \mathrm{l}$ & 26.4 & 37.10 & 14.7 & 12.16 \\
\hline $\mathbf{F e}$ & $\mathrm{mg} / \mathrm{l}$ & 0.32 & 0.66 & 0.08 & 0.16 \\
\hline $\mathbf{Z n}$ & $\mathrm{mg} / \mathrm{l}$ & 0.12 & 0.25 & 0.02 & 0.07 \\
\hline $\mathbf{C u}$ & $\mathrm{mg} / \mathrm{l}$ & 0.06 & 0.11 & $<0.05$ & 0.05 \\
\hline $\mathbf{P b}$ & $\mathrm{mg} / \mathrm{l}$ & $<0.05$ & $<0.05$ & $<0.05$ & $<0.05$ \\
\hline $\mathbf{C r}$ & $\mathrm{mg} / \mathrm{l}$ & 0.007 & 0.036 & 0.019 & 0.025 \\
\hline $\mathbf{M n}$ & $\mathrm{mg} / \mathrm{l}$ & $<0.05$ & 0.08 & $<0.05$ & $<0.05$ \\
\hline Temperature & ${ }^{\circ} \mathrm{C}$ & $22^{\circ} \mathrm{C}$ & $21^{\circ} \mathrm{C}$ & $25^{\circ} \mathrm{C}$ & $29^{\circ} \mathrm{C}$ \\
\hline
\end{tabular}

The $\mathrm{pH}$ is a measure of the acidic or basic (alkaline) nature of a solution. The concentration of the hydrogen ion $\left[\mathrm{H}^{+}\right]$activity in a solution determines the $\mathrm{pH}$. Mathematically this is expressed as:

$$
\mathbf{p H}=-\log \left[\mathbf{H}^{+}\right]
$$

The $\mathrm{pH}$ value is the negative power to which 10 must be raised to equal the hydrogen ion concentration (Kumar \&Puri, 2012). The overall pH ranges from $6.5-7.1$ for the stream water sample site 5 to site 8 . It was found that stream water samples site 5 , site 7 and site 8 were slightly acidic and the stream water sample site 6 is neutral from Table 3.6 above. The mean $\mathrm{pH}$ of the water samples is 6.8 , which is an indication that the stream water along the quarry is slightly acidic water. The stream water along the quarry comes in contact with metal ions from minerals and rock mass in the presence of atmospheric air to form acidic waters mixed with heavy metals. The $\mathrm{pH}$ of water generally influences the concentration of many metals by altering their availability and toxicity (Swer and Singh, 2014). The mean pH 6.8 of the water sample falls within the WHO (2012) and Nigerian Industrial Standard (NIS, 2007) requirement for consumable water which is in the $\mathrm{pH}$ range of $6.5-$ 8.5 (Das et al., 2012).

The temperature of the four River Onyami water samples are $22^{\circ} \mathrm{C}, 21^{\circ} \mathrm{C}, 25^{\circ} \mathrm{C}$ and $29^{\circ} \mathrm{C}$ from Table 3.6 above, with a mean temperature of $24.3^{\circ} \mathrm{C}$. According to WHO's (2008) guideline for drinking water, the maximum limit of temperature for drinkable water should be below $30^{\circ} \mathrm{C}$. The temperature of the water $\left(24.3^{\circ} \mathrm{C}\right)$ meets the WHO's (2008) requirement. Water temperature regulates the metabolism of the aquatic ecosystem. High water temperature stress aquatic ecosystem by reducing the ability of water to hold essential dissolved gases like oxygen (Kumar \&Puri, 2012). Temperature has a noticeable influence on the chemical and biochemical reactions that occur in water bodies, high temperature increases the toxicity of heavy metals and it also increases the sensitivity of living organisms to toxic substance (Mombaet al., 2006).

From Tables 3.6 above, the electrical conductivity (EC) in the study area ranges from $22 \mu \mathrm{S} / \mathrm{cm}$ to $30 \mu \mathrm{S} / \mathrm{cm}$. Electrical Conductivity of the stream water is the sum of ionic conductance of all the ionic constituents. It depends upon dissolved nutrient and micronutrients of the stream water samples. The mean electrical conductivity of the four stream water samples is $27 \mu \mathrm{S} / \mathrm{cm}$ which is very low. The Nigerian Industrial Standard (2007) stipulated a maximum permissible limit of $1000 \mu \mathrm{S} / \mathrm{cm}$. The more the dissolved solids in water are, the more the electrical conductivity (Tekade, 2011). These findings are not in conformity with the observation of (Rao et al., 2012; Patil and Patil, 2010) who recorded higher conductivity of the stream water samples ranging between $755-1898 \mu \mathrm{S} / \mathrm{cm}, 386-2827 \mu \mathrm{S} / \mathrm{cm}$ and $400-3500 \mu \mathrm{S} / \mathrm{cm}$, respectively. However, high electrical conductivity content in the stream water around the quarry may indicate dissolution of minerals due to quarrying of rock mass. The 
higher electrical conductivity value might also be due to the presence of high amount of dissolved inorganic substances in ionized form (Kerkettaet al., 2013) and low electrical conductivity might be due to the absence of dissolved inorganic substances and dissolved nutrients.

Dissolved oxygen analysis measures the amount of gaseous oxygen $\left(\mathrm{O}_{2}\right)$ dissolved in an aqueous solution. Oxygen gets into water by diffusion from the surrounding air, by aeration (rapid movement) and as a waste product of photosynthesis. Dissolved Oxygen (DO) values of the stream water samples site 5, site 6 , site 7 and site 8 , are 8, 7.6, 2.8 and $6.4 \mathrm{mg} / \mathrm{l}$ respectively from Table 3.6. If the dissolved oxygen of stream water is less than $3 \mathrm{mg} / \mathrm{l}$, it will be stressful to most aquatic organisms. At least 5 $6 \mathrm{mg} / \mathrm{l}$ are usually required for growth of aquatic organisms (Tekadeet al., 2011). According to WHO (2008) guidelines for drinking water, the minimum permissible limit for Dissolve Oxygen in drinkable water is $5.0 \mathrm{mg} / \mathrm{l}$ (WHO, 2008). The mean DO for the stream water is $6.3 \mathrm{mg} / \mathrm{l}$, which is relatively higher than the WHO (2008) minimum permissible limits. The high DO in the stream water may be due to low temperature of the stream, decrease molecular activities and low quantity of water organisms. Low DO can be due to metal contamination in quarry stream water, which can cause serious problems (Dhal et al., 2011) and poorly aeration of the water which generally decreases downstream. The DO is essential for sustaining higher forms of life in water bodies and it is an important parameter to assess water quality.

Biochemical Oxygen Demand (BOD) is used to indicate the extent of organic pollution in aquatic system which adversely affects the water quality (Igbinosaet al., 2012). Biochemical Oxygen Demand of the stream water from Table 3.6 above, ranges between 0.4 to $4.8 \mathrm{mg} / 1$ with a mean of $2.6 \mathrm{mg} / 1$, and it is in slight accordance with a research conducted by Usharaniet al., (2010), who found that biochemical oxygen demand ranges from $0.16-11.6 \mathrm{mg} / \mathrm{l}$. Water with BOD $<4 \mathrm{mg} / \mathrm{l}$ are considered to be polluted and unsafe (Kurupet. al., 2011). High BOD has undesirable consequences on aquatic life such as leading to production of ammonia and hydrogen sulphide, which causes negative effect on fish (Boyd and Lichikoppler, 1979). Increased biological oxygen demand (BOD) may suggest increased organic matter $(\mathrm{OM})$ within the stream from industrial discharge, wastewater effluents and inability of self-purification (Phiri et al., 2005; Akan et al., 2007; 2008). Therefore, the quarry stream water with a mean BOD of $2.6 \mathrm{mg} / 1$ meet the universal water requirement index of $3 \mathrm{mg} / \mathrm{l} \mathrm{BOD}$ (Boyacioglu, 2007).

The calcium concentrations of the stream water samples from site 5, site 6 , site 7 and site 8 are 3.64 , $4.28,2.66$ and $3.56 \mathrm{mg} / \mathrm{l}$ respectively from Table 3.6 above, and the mean concentration of calcium is $3.50 \mathrm{mg} / \mathrm{l}$ which is below the $70 \mathrm{mg} / \mathrm{l}$ maximum level prescribed by WHO (1973) for drinkable water.

The concentration of sulphate in the four River Onyami water samples from Table 3.6 above in site 5, site 6 , site 7 and site 8 are $0.32,0.40,0.39$ and $0.33 \mathrm{mg} / 1$ respectively, with mean concentration of $0.36 \mathrm{mg} / \mathrm{l}$. The mean concentration of $0.36 \mathrm{mg} / \mathrm{l}$ is far below the permissible limit of $100 \mathrm{mg} / \mathrm{l}$ as prescribed by NIS (2007), and which if exceeded will cause greasy feel and laxative effect in water (Robillard et al., 2015).

The water hardness depends on anions such as carbonate and bicarbonate. The total hardness (THardness) values of the water samples from Table 3.6 above in site 5 , site 6 , site 7 and site 8 ranges from $3.60-7.10 \mathrm{mg} / \mathrm{l}$. It has a mean of $5.5 \mathrm{mg} / \mathrm{l}$ which does not exceed the NIS (2007) standard of $150 \mathrm{mg} / \mathrm{l}$. The water hardness has no known adverse effects on the environment (Dhal et al., 2011) but high hardness creates problems for daily human usage (Das et al., 2012).

The phosphate values of the quarry stream water reported are not similar to those reported by Das et al., (2012). The phosphate values of the stream water from Table 3.6 above is in the range of $0.06 \mathrm{mg} / \mathrm{l}$ - $0.13 \mathrm{mg} / \mathrm{l}$. Phosphate is a critical nutrient element for the growth of microorganisms like algae in water (Trivedi and Goel, 1984) and can cause eutrophication when the concentration in the stream water is high. The mean value of the phosphate concentration in the stream water sample is $0.09 \mathrm{mg} / \mathrm{l}$, which is below the prescribed WHO standard maximum permissible limit for drinkable water which is 5mg/l, and above the FEPA (1991) limit of $<0.05 \mathrm{mg} / \mathrm{l}$ for aquatic life, irrigation purposes, livestock watering and recreational activities.

The of the total dissolved solids (TDS) for the four stream water samples ranges from 11, 13, 14 and $15 \mathrm{mg} / \mathrm{l}$ and the mean value is $13.25 \mathrm{mg} / \mathrm{l}$. it was observed that the four water samples were below the 
permissible limit of $1000 \mathrm{mg} / \mathrm{l}$ prescribed by WHO (1973) and 500mg/l as prescribed by NIS (2007). These findings are not in line with Kerkettaet al., (2013) who reported TDS values to be in the range from $67-1846 \mathrm{mg} / \mathrm{l}$. However, the presence of high levels of TDS in water may be objectionable to consumers owing to the resulting taste and excessive scaling in water pipes, heaters, boilers and household appliances. Some dissolved organic matter may contribute to increased level of TDS which also indicates that the water is polluted (Rao et al., 2012). Also, water with extremely low concentrations of TDS may be unacceptable to consumers because of its flat and insipid taste. High TDS might be due to the presence of large number of organic salts as carbonate, bicarbonate, sodium, potassium and calcium, and also some non-volatile substances which are solid at room temperature (Kerkettaet al., 2013).

The overall range of alkalinity of water samples examined was from $15.5-30.6 \mathrm{mg} / \mathrm{l}$ and the mean value is $22.3 \mathrm{mg} / \mathrm{l}$. It is against the findings observed by Belorkar (2010) who recorded alkalinity levels up to $250 \mathrm{mg} / \mathrm{l}$ in the river water. The value of alkalinity may be due to high temperature in summer and increased levels of bicarbonate because of high rate of photosynthesis. The findings are also not in conformity with Patil and Patil (2010) and Krishnan et al. (2010), who recorded higher alkalinity value ranging from $170-870 \mathrm{mg} / \mathrm{l}$ and $210-910 \mathrm{mg} / \mathrm{l}$ respectively. Therefore, the variation in alkalinity of water is due to the presence of bicarbonate, carbonate and hydroxide compound of calcium, sodium and potassium (Kerkettaet al., 2013).

The concentration of nitrate $\left(\mathrm{NO}_{3}\right)$ ranges from $0.68,2.70,1.77$ and $0.52 \mathrm{mg} / \mathrm{l}$, with a mean concentration of $1.42 \mathrm{mg} / \mathrm{l}$. The maximum acceptable limit is $4.5 \mathrm{mg} / \mathrm{l}$ (Robillard et al., 2015). It sources might be as a result of soil by-product of agricultural fertilization and human and animal waste leaching to ground water. If it is in excess or above acceptable limit, it may result to methemoglobinemia (blue baby disease) in infants (from birth -6 months) and low health threat to children and adults (Robillard et al., 2015).

The concentration of ammonium-nitrogen $\left(\mathrm{NH}_{4}-\mathrm{N}\right)$ from Table 3.6 are $0.13,0.15,0.07$ and $0.12 \mathrm{mg} / \mathrm{l}$ with mean of $0.09 \mathrm{mg} / \mathrm{l}$. Ammonium nitrogen and nitrate are essential nutrients to plant life, but when found in excessive quantities, they can stimulate excessive and undesirable plant growth such as algal blooms (Igbinosaet al., 2012). Eutrophication could adversely affect the use of rivers and dams for recreational purposes as the covering of large areas by blue green algae and or mycrophytes that can release toxic substances (cyanotoxins) could prevent access to waterways (Igbinosa and Okoh, 2009).

The mean concentration of chromium in the four stream water sample is $0.022 \mathrm{mg} / \mathrm{l}$ which does not exceed the critical limit of $0.1 \mathrm{mg} / \mathrm{l}$ (USEPA, 1999) and the maximum permissible limit of $0.05 \mathrm{mg} / \mathrm{l}$ (WHO, 1982).

The mean concentration of zinc $(0.12 \mathrm{mg} / \mathrm{l})$ in the four water sample from Table 3.7 shows a lower concentration, compared to the International Standard limit of $<1.0 \mathrm{mg} / \mathrm{l}$ (Das et al., 2012) and it does not exceed the maximum permissible limit of 5mg/l (WHO, 1996) and 3mg/l (NIS, 2007). Therefore, the water can be used for either drinking or domestic application.

Table13. Soil quality criteria for some standard organisations compared with the present study

\begin{tabular}{|c|c|c|c|c|c|c|c|c|c|c|c|c|}
\hline $\mathrm{Z}$ & & & & \multicolumn{9}{|c|}{ Permissible limits by various standard organisations } \\
\hline 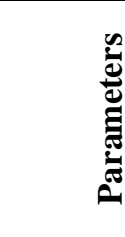 & $\stackrel{\mathscr{\Xi}}{\mathscr{\Xi}}$ & 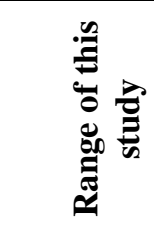 & 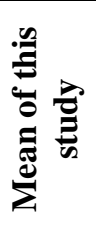 & 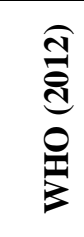 & 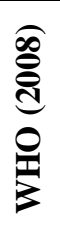 & $\begin{array}{l}\frac{1}{5} \\
2 \\
0 \\
0 \\
2 \\
3\end{array}$ & 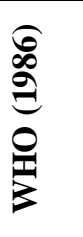 & 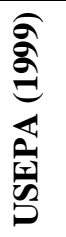 & 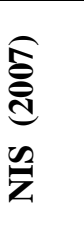 & 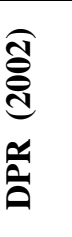 & 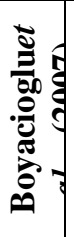 & 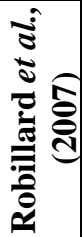 \\
\hline pH & & $6.5-7.1$ & 6.75 & $\begin{array}{l}6.5- \\
8.5\end{array}$ & & & & $\begin{array}{l}6.5- \\
8.5\end{array}$ & $\begin{array}{l}6.5- \\
8.5\end{array}$ & & & \\
\hline $\mathbf{E C}$ & $\mathrm{uS} / \mathrm{cm}$ & $\begin{array}{c}22.0- \\
30.0\end{array}$ & 26.50 & & & & 300 & & 1000 & & & \\
\hline TDS & $\mathrm{mg} / \mathrm{l}$ & $\begin{array}{c}11.0- \\
15.0\end{array}$ & 13.25 & 1000 & & & 1000 & & 500 & & & \\
\hline TSS & $\mathrm{mg} / \mathrm{l}$ & $0.06-0.18$ & 0.11 & & & & & & & & & \\
\hline DO & $\mathrm{mg} / \mathrm{l}$ & $2.80-8.00$ & 6.20 & & 5.0 & & & & & $\begin{array}{l}7.5- \\
8.5\end{array}$ & & \\
\hline
\end{tabular}


Baseline Levels of the Chemical Parameters in the Vicinity of Quarry Industries in Igarra, Akoko Edo Local Government, Edo State

\begin{tabular}{|c|c|c|c|c|c|c|c|c|c|c|c|c|}
\hline BOD & $\mathrm{mg} / \mathrm{l}$ & $2.1-4.8$ & 2.63 & & & & & & & & 3 & \\
\hline $\mathbf{C a}$ & $\mathrm{mg} / \mathrm{l}$ & $2.66-4.28$ & 3.54 & & & 70 & 75 & & & & & \\
\hline Mg & $\mathrm{mg} / \mathrm{l}$ & $0.78-2.16$ & 1.48 & & 50 & & 30 & & 0.2 & & & \\
\hline $\begin{array}{c}\text { T- } \\
\text { HARDNESS }\end{array}$ & $\mathrm{mg} / \mathrm{l}$ & $3.60-7.10$ & 5.46 & & & & 500 & & & & & \\
\hline $\mathrm{PO}_{4}$ & $\mathrm{mg} / \mathrm{l}$ & $0.06-0.13$ & 0.093 & 5.0 & & & & & & & & \\
\hline $\mathrm{SO}_{4}$ & $\mathrm{mg} / \mathrm{l}$ & $0.32-0.40$ & 0.36 & & & & 500 & & & & & \\
\hline $\mathrm{NO}_{3}$ & $\mathrm{mg} / \mathrm{l}$ & $0.52-2.70$ & 1.42 & & & 45 & 50 & & & & & \\
\hline $\mathrm{NH}_{4}-\mathbf{N}$ & $\mathrm{mg} / \mathrm{l}$ & $0.07-0.15$ & 0.12 & & & & & & & & & \\
\hline $\mathrm{Na}$ & $\mathrm{mg} / \mathrm{l}$ & $4.40-6.31$ & 5.33 & & & & & & 200 & & & \\
\hline $\mathbf{K}$ & $\mathrm{mg} / \mathrm{l}$ & $5.72-8.20$ & 6.93 & & & & 20 & & & & & \\
\hline Alkalinity & $\mathrm{mg} / \mathrm{l}$ & $15.5-30.6$ & 22.3 & & & 250 & 200 & & & & & \\
\hline Chloride & $\mathrm{mg} / \mathrm{l}$ & $\begin{array}{l}12.16- \\
37.10 \\
\end{array}$ & 22.59 & & & 250 & 250 & 250 & 250 & & & 250 \\
\hline $\mathbf{F e}$ & $\mathrm{mg} / \mathrm{l}$ & $0.08-0.66$ & 0.31 & & & 0.3 & 0.1 & & 0.30 & & & \\
\hline $\mathbf{Z n}$ & $\mathrm{mg} / \mathrm{l}$ & $0.02-0.25$ & 0.12 & & & & 5.0 & & & 0.8 & & \\
\hline $\mathbf{C u}$ & $\mathrm{mg} / \mathrm{l}$ & $0.05-0.11$ & 0.068 & & & & 1.0 & 1.3 & & 0.08 & & \\
\hline $\mathbf{P b}$ & $\mathrm{mg} / \mathrm{l}$ & $0.05-0.05$ & 0.05 & & & & 0.05 & & 0.01 & 0.08 & & \\
\hline $\mathrm{Cr}$ & $\mathrm{mg} / \mathrm{l}$ & $\begin{array}{c}0.007- \\
0.036\end{array}$ & 0.022 & & & & 0.4 & 0.1 & 0.2 & $\mathbf{0 . 0 3}$ & & \\
\hline Mn & $\mathrm{mg} / \mathrm{l}$ & $0.05-0.08$ & 0.058 & & & & 0.5 & & & & & \\
\hline Temp. & ${ }^{\circ} \mathrm{C}$ & $21-29$ & 24.30 & & 30 & & & & & & & \\
\hline
\end{tabular}

Table14. Water quality criteria for some standard organizations compared with the present study

\begin{tabular}{|c|c|c|c|c|c|c|c|c|c|c|c|c|c|}
\hline \multirow[b]{2}{*}{ 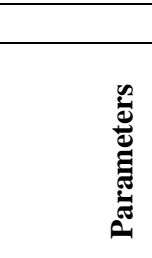 } & \multirow[b]{2}{*}{$\stackrel{\mathscr{B}}{\Xi}$} & \multirow[b]{2}{*}{ 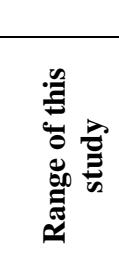 } & \multirow[b]{2}{*}{ 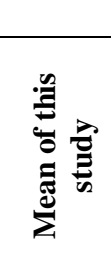 } & \multicolumn{10}{|c|}{ Permissible limits values by some various standard organisations } \\
\hline & & & & 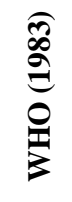 & $\begin{array}{l}\stackrel{0}{2} \\
2 \\
0 \\
2\end{array}$ & $\begin{array}{l}\stackrel{\widehat{\sigma}}{\sigma} \\
\frac{\alpha}{\hat{\sigma}}\end{array}$ & 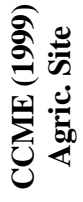 & 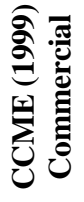 & 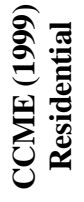 & 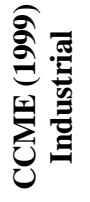 & 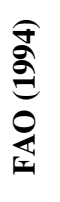 & 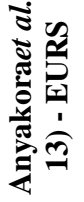 & 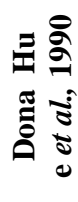 \\
\hline pH & & $6.5-7.2$ & 6.8 & & & & 6-8 & 6-8 & 6-8 & 6-8 & & & \\
\hline EC & $\mathrm{uS} / \mathrm{cm}$ & $\begin{array}{c}226- \\
304 \\
\end{array}$ & 264.33 & & & & 2 & 4 & 2 & 4 & 2 & & 4 \\
\hline $\mathrm{Ca}$ & $\mathrm{mg} / \mathrm{l}$ & $\begin{array}{l}138.6- \\
160.90\end{array}$ & 148.97 & & & & & & & & & & \\
\hline Mg & $\mathrm{mg} / \mathrm{l}$ & $\begin{array}{l}98.18- \\
125.70\end{array}$ & 110.03 & & & & & & & & & & \\
\hline $\mathbf{N a}$ & $\mathrm{mg} / \mathrm{l}$ & $\begin{array}{l}45.20- \\
125.70 \\
\end{array}$ & 52.87 & & & & & & & & & & \\
\hline $\mathbf{K}$ & $\mathrm{mg} / \mathrm{l}$ & $\begin{array}{l}58.76- \\
79.04 \\
\end{array}$ & 68.73 & & & & & & & & & & \\
\hline $\mathrm{PO}_{4}$ & $\mathrm{mg} / \mathrm{l}$ & $\begin{array}{l}3.62- \\
7.44\end{array}$ & 5.60 & 0.4 & & & & & & & 0.4 & & \\
\hline $\mathrm{SO}_{4}$ & $\mathrm{mg} / \mathrm{l}$ & $\begin{array}{c}11.42- \\
16.13 \\
\end{array}$ & 13.48 & 200 & & & & & & & & & \\
\hline Cl & $\mathrm{mg} / \mathrm{l}$ & $\begin{array}{l}133.80- \\
158.20 \\
\end{array}$ & 146.17 & 250 & & & & & & & & & \\
\hline Alkalinity & $\mathrm{mg} / \mathrm{l}$ & $\begin{array}{c}97.40- \\
118.3 \\
\end{array}$ & 107.23 & & & & & & & & & & \\
\hline $\mathrm{NH}_{4}-\mathrm{N}$ & $\mathrm{mg} / \mathrm{l}$ & $\begin{array}{l}7.46- \\
13.67\end{array}$ & 10.15 & $\begin{array}{l}10- \\
50\end{array}$ & & & & & & & & & \\
\hline EA & $\mathrm{mg} / \mathrm{l}$ & $\begin{array}{l}98.65- \\
110.40\end{array}$ & 104.06 & & & & & & & & & & \\
\hline CEC & $\mathrm{mg} / \mathrm{l}$ & $\begin{array}{c}357.76- \\
426.44\end{array}$ & 484.65 & & & & & & & & & & \\
\hline TOC & $\mathrm{mg} / \mathrm{l}$ & $\begin{array}{c}0.41- \\
0.49\end{array}$ & 0.50 & & & & & & & & & & \\
\hline Clay & $\mathrm{mg} / \mathrm{l}$ & $\begin{array}{l}6.31- \\
8.22 \\
\end{array}$ & 6.87 & & & & & & & & & & \\
\hline Silt & $\mathrm{mg} / \mathrm{l}$ & $\begin{array}{c}3.61- \\
6.70\end{array}$ & 4.87 & & & & & & & & & & \\
\hline Sand & $\mathrm{mg} / \mathrm{l}$ & $87.12-$ & 88.26 & & & & & & & & & & \\
\hline
\end{tabular}


Baseline Levels of the Chemical Parameters in the Vicinity of Quarry Industries in Igarra, Akoko Edo Local Government, Edo State

\begin{tabular}{|c|c|c|c|c|c|c|c|c|c|c|c|}
\hline & & 90.18 & & & & & & & & & \\
\hline POM & $\mathrm{mg} / \mathrm{l}$ & $\begin{array}{c}0.68- \\
0.97\end{array}$ & 0.80 & & & & & & & & \\
\hline $\mathbf{F e}$ & $\mathrm{mg} / \mathrm{l}$ & $\begin{array}{l}239.65- \\
322.15\end{array}$ & 279.26 & 200 & & & & & & & 1500 \\
\hline $\mathbf{Z n}$ & $\mathrm{mg} / \mathrm{l}$ & $\begin{array}{l}92.54- \\
128.60\end{array}$ & 106.03 & & 146 & 200 & 360 & 200 & 360 & & \\
\hline $\mathrm{Cu}$ & $\mathrm{mg} / \mathrm{l}$ & $\begin{array}{c}52.30- \\
82.16\end{array}$ & 65.67 & & 36 & 63 & 91 & 63 & 91 & & 30 \\
\hline $\mathbf{P b}$ & $\mathrm{mg} / \mathrm{l}$ & $\begin{array}{c}16.75- \\
63.10\end{array}$ & 33.33 & & 85 & 70 & 260 & 140 & 600 & & 150 \\
\hline $\mathrm{Cr}$ & $\mathrm{mg} / \mathrm{l}$ & $\begin{array}{c}11.27- \\
17.67\end{array}$ & 14.59 & & 100 & 64 & 87 & 64 & 87 & 100 & 100 \\
\hline Mn & $\mathrm{mg} / \mathrm{l}$ & $\begin{array}{l}34.74- \\
152.13\end{array}$ & 98.16 & 200 & & 64 & 87 & 64 & 87 & & 200 \\
\hline
\end{tabular}

\section{CONCLUSION AND SUGGESTION}

The baseline levels of the chemical parameters in the vicinity of the quarry industries, Igarra, from this study, revealed that the concentration of the heavy metals and their physicochemical properties do not vary widely.

The results of the physicochemical analysis of the soil samples do not exceed their permissible limits except for phosphate. The high level of sand suggested that the soil will have weak surface aggregation; high rate of water infiltration, metal ions would be leached to the subsoil and thereafter into ground water to cause pollution.

However, the levels of heavy metals in the stream obtained from this study when compared with standard for metals suggested that they are relatively below their permissible limits, except for iron which is higher than its permissible limit. Manganese in the stream water in relation to other metals may pose environmental risk threat because it has aa higher contamination factor.

There is therefore the need to continually assess their nature, usage, transportation, volume and direct harmful effect on the environment. Since the physicochemical analysis of River Onyami meets the basic requirement for drinking water, it can be used for irrigation and other domestic purposes.

To be safe however, continuous monitoring of the stream water and control of quarrying activities is important to check irregularities which could pose great threat soon.

\section{Suggestions for Further Studies}

Nutrient quality concentration comparism between the various quarry rock samples in Igarra in the production of essential household consumables and building materials.

\section{REFERENCES}

[1] Abua, M.A. and Edet, O.E. (2007): Morphological and physico-chemical characteristics of coastal plain soils of Southern Cross River State- Nigeria. Nigeria Geographical Journal, 5(1): 109-114.

[2] Abua, M.A. and Edet, O.E. (2013): Assessment of soils around quarry terrain in Akamkpa Local government area, Cross River State-Nigeria. Merit Research Journal of Agricultural Science and Soil Sciences,1(1): 001-005.

[3] Adulaji, E.A. and Ekong, E.E. (1981): General Agriculture And Tool. London Cassell, Pp100 - 106.

[4] Agronomic Spotlight - Soil Testing (2015):Interpreting Soil Sample Results - North Dakota; retrieved from; http://www.aganytime.com/Soybeans/Pages/Article.aspx?name=Interpreting- Soil-Sample-Results--North-Dakota\&fields=article\&article $=91$.

[5] Akan, J. C., Abdulrahman, F. I., Dimari, G, A. and Ogugbuaja, V. O. (2008): Physicochemical determination of pollutants in wastewater and Vegetable samples along the Jakara Wastewater Channelin Kano Metropolis, Kano State, $\quad$ Nigeria. Europ. J.Sci.Res.,23(1):122-133.

[6] Akan, J. C., Abdulrahman, F. I., Ayodele, J. T. and Ogugbuaja, V.O. (2007): Studies on the effect of Municipal waste and Industrial effluents on the Pollutant level of River Challawa, Kano State, Nigeria. Res. J. Appl. Sci., 2(4):530-535.

[7] Akande, J. M., Lawal, A. I. and Adeboye, W. A. (2013): Evaluation of the Environmental Effects of the Abandoned Quarries: Strabag Quarry at Ibadan, Nigeria and RCC Nigeria; Journal of Environment and Earth Science, 3(4):2224 -3216. Quarry at Wasinmi, Ikire, 
[8] Akande, J.M. and Awojobi, D.A. (2003): Assessment Of Environmental Impacts Of Exploitation Of Granite Deposits In Ilorin, Journal Of Engineering and Technology, 10(2):4891 - 4900.

[9] Anegbe, B., Okuo, J.M., Ewekay, E.O. and Ogbeifun, D.E. (2014): Fractionation Of Lead-Acid Battery Soil Amended With Biochar; Bayero Journal of Pure and Applied Sciences, 7(2):36 - 43.

[10] Anyakora, C., Ehianeta, T. and Umukoro, O. (2013): Heavy metal levels in soil samples from highly industrialized Lagos environment; African Journal of Environmental Science and Technology, 7(9):917924.

[11] APHA (1971): Standard methods for the examination of waste and wastewater. Washington D.C., p874.

[12] APHA (1975): Standard methods for the examination of waste and wastewater. $19^{\text {th }}$ Edn., American Public Health Association.

[13] APHA (1992): Standard Methods for Examination of Water and waste 18th ed. American Public health Association, Washing ton D.C.

[14] APHA (1998): Standard methods for the examination of waste and wastewater. Washington D.C., part $4500-\mathrm{SO}_{4}{ }^{2-}, \mathrm{E}: 4-178$.

[15] APHA (1998): Standard methods for the examination of waste and wastewater. Washington D.C., part 2340, C: 2-36.

[16] APHA (2005): Standard methods for the examination of waste and wastewater; Dissolved Oxygen; Washington D.C., part 4500 - OC, 4-131.

[17] Belorkar, S.A. (2010): Assessment of the deterioration in physio-chemical and microbiological quality of Shivnath River Water in Durg District, India. E-J. Chem., 7(3):733 -738.

[18] Berry, P. and Pistocchi, A. (2003): A multicriterial geographical approach to environmental impact assessment of open pit quarries: International journal of surface mining reclamation and environment, 17(4): 213-226.

[19] BER Policy (2004): Investigation and Remediation of salt (chloride) impacted soil and groundwater; Bureau of Environmental Remediation/Remedial Section Guidance, p1-8.

[20] Bickelhaupt, D. (2015): Soil pH: What it means. Retrieved on 11/06/2015 from http://www.esf.edu/pubprog/brochure/soilph/soilph.htm.

[21] Boyacioglu, H. (2007). Development of a water quality index based on a Eur. classification scheme. Water $S A, 33: 101-106$.

[22] Boyd, C. E. and Lichikoppler, F. (1979): Water quality in fish pond culture research and development. International Center for Agriculture. Experimental Station, Aubm.

[23] Bouyoucos, G.J. (1962): Hydrometer method improved for making particle size analyses of soils, Agronomy Journal, 53:464 -465.

[24] Black, G.R. (1965): Particle Density Methods of Soil Analysis, Part 1. In: C.A. Black American Society of Agronomy Monograph, No. 9.

[25] Bray, R.M. and Kurtz, L.T. (1947): Determination of Total Organic and Available form of Phosphorus in Soil. Soil Science, 56:39-45.

[26] CCME (1991): Canadian Council of Ministers of the Environment; Canadian Soil Quality Guidelines for theprotection of environment and human health; Summary Tables.

[27] Clemson Public Service Activities (2015): CEC, acidity, and percent base saturation; Agricultural ServiceLaboratory;retrievedfrom;http://www.clemson.edu/public/regulatory/ag_svc_lab/soil_testing/cec.ht $\mathrm{ml}$ on $18 / 03 / 2015$.

[28] Das, S., Patnaik, S.C., Sahu, H.K., Chakraborty, A., Sudarshan, M. and Thatoi, H.N. (2012): Heavy metal contamination, physico-chemical and microbial evaluation of water samples collected from chromite mine environment of Sukinda, India; Science Direct; Trans. Nonferrous Met. Soc. China, 23: 484-493.

[29] Dhal, B., Das, N.N., Pandey, B.D. and Thatoi, H.N. (2011): Environmental quality of the Boula-Nuasahi chromite mine area in India. Journal of Mine Water and the Environment, 30(3):191-196.

[30] Donahue, R.L.O., Miller, R.W. and Shickluna, J.C. (1990): Soil: An Introduction to Soil and Plant Growth, Fifth Edition Prentice Hall India Private limited New Delhi, 667p.

[31] DPR (1991): Department of Petroleum Resources, Environmental Guidelines and Standards for Petroleum Industry in Nigeria; Target and Intervention Values for metals in soils.

[32] FAO/WHO (1997): Expert committee food additives would health organization, Geneva. WHO Technical Report series (FAO) Rome 1(2):20-26.

[33] Fatoye, F. B. and Gideon, B.Y. (2013): Geology and Occurrences of Limestone and Marble in Nigeria; Journal of Natural Sciences Research, 3(11). 
[34] Gbadegesin, A.S. and Abua, M.A. (2011): Variation of Soil Properties on Cassava Production in the Coastal Area of Southern Cross River State, Nigeria. J. Geography and Geol., 3(1):94-103.

[35] Gibbs, P.E., Bebianno, M.J. and Coelho, M.R. (1997): Evidence of the Differential Sensitivity of Neogastropods to Tributyltin Tbt Pollution, With Notes on Species ColumbellaRustica Lacking the Imposex Response. Environ. Technol., 18:1219-1224.

[36] Igbinosa, E.O., Uyi, O.O., Odjadjare, E.E., Ajuzie, C.U.,Orhue, P.O. and Adewole, E.M. (2012): Assessment of physicochemical qualities, heavy metal concentrations and bacterial pathogens in Shanomi Creek in the Niger Delta, Nigeria; African Journal of Environmental Science and Technology, 6(11):419-424.

[37] Igbinosa, E.O. and Okoh, A.L. (2009): Impact of discharge wastewater effluents on the physico-chemical qualities of a receiving watershed in a typical rural community. Int'l. J. Sci. Tech., 6:175-182.

[38] Jenne, E.A. (1968) Trace Inorganics in Water, A \&. Chem. Ser., 73:337-387

[39] Jones, G. and Bradshaw, B. C. (1933): The measurement of the conductance of electrolytes: Are determination of the conductance of the standard potassium chloride solutions in absolute units, J. Amer, Chem. Soc., 55:1780.

[40] Kabala, C. and Singh, B. R. (2001): Fractionation and Mobility of Copper, lead, and zinc in Soil Profile in the vicinity of a Copper Smelter, Journal of Environmental Quality, 30:485-495.

[41] Kadem, D.E.D., Rached, O., Krika, A. and Gheribi-Aoulmi, Z. (2004):Statistical analysis of vegetation incidence on contamination of soils by heavy metals $(\mathrm{Pb}, \mathrm{Ni}$ and $\mathrm{Zn}$ ) in the vicinityof an iron steel industrial plant in Algeria. Environmetrics, 15:447-462

[42] Kerketta, P., Baxla, S.L., Gora, R.H., Kumari, S. and Roushan, R.K. (2013): Analysis of physico-chemical properties and heavy metals in drinking water from different sources in and around Ranchi, Jharkhand, India, 6(7):370-375.

[43] Krishnan, R. R., Dharmaraj, K. and Kumari, B.D.R. (2007): A comparative study on the physicochemical and bacterial analysis of drinking, borewell and sewage water in the three different places of Sivakasi. $J$. Env. Biol.,28(1):105-108

[44] Kumar, M. and Puri, A. (2012): A review of permissible limits of drinking water, Indian J Occup Environ Med., 16(1):40-44.

[45] Kurup, R., Persaud, R., Caesar, J. and Raja, V. (2011): Microbiological and physiochemical analysis of drinking water in Georgetown, Guyana. Nat. Sci.,8(8): 261-265.

[46] Lim, P. and Kiu, M. (1995): Determination and Speciation of Heavy Metals in Sediments of the Juru river, Penang, Malaysia. Environ. Monit. Assess, 35:85-95.

[47] Momba, M.N.B., Tyafa, Z., Makala, N., Brouckaert, B.M. and Obi, C.L. (2006): Safe drinking water, still a dream in rural areas of South Africa. Case study: The Eastern Cape Province. Water SA,32:715-720.

[48] Muller, G. (1969): Index of geoaccumulation in sediments of the Rhine River. Geo.2:108-118.

[49] Nigerian Industrial Standard (2007): Nigerian Standard for Drinking Water; Standard Organisation of Nigeria (SON), pp $1-30$.

[50] Obasi, R.A. (2012): Geochemistry and Appraisal of the Economic Potential of Calc -Gneiss and Marble from Igarra, Edo State, Southwest, Nigeria, ARPN Journal of Science and Technology.,23(7):124 - 134.

[51] Obasi, R. and Isife, F. (2012): Geochemistry and economic potential of marble from Ikpeshi, South-West, Nigeria. ARPN Journal of Engineering and Applied Sciences, pp 773 - 779.

[52] Okuo, J.M. and Okolo, P.O. (2011): Thermodynamic assessment of anionic ligand-modified palm kernel fibre in the sorption of some toxic metals. Global J. Pure and Appl. Sci., 17(1): 113-116.

[53] Olumayede, E.G. and Okuo, J.M. (2012): Variation characteristics of volatile organic compounds in an urban atmosphere in Nigeria, Pol J. Environ. Stud., 21(1): 177-186.

[54] Omosanya, K.O. and Ajibade, O.M. (2011):Environmental impact of quarrying on Otere Village,Odeda, Southwestern Nigeria. Ozean Journal of Applied Sciences, 4(1): 75 - 82.

[55] Oosterbaan, R.J. (2003): Soil Alkalinity(Alkaline-sodic soils), International Course on Land Drainage (ICLD); International Institute for Land Reclamation and Improvement (ILRI), Wageningen, The Netherlands, p 1-7.

[56] Pascal,B.(2011):TheChemicalCompositionof Marble; retrieved from; www.science360.com/index.php/thechemical-composition-of-marble-5059; on 11/11/2014.

[57] Patil, V.T. and Patil, P.R. (2010): Physico-chemical analysis of selected ground water samples of Amalner Town in Jalgaun District, Maharastra, India. E- J. Chem., 7(1): 111 - 116.

[58] Phiri, O., Mumba, P., Moyo, B. H. and Kadewa, W. (2005): Assessment of the impact of industrial effluent on water quality of receiving rivers in urban areas of Malawi. Int. J. Environ. Sci. Tech., 2(3):237-244. 
[59] Rajput, R. K. (2008): Engineering materials S.Chand $3^{\text {rd }}$ edition, New Delhi. P. 89-94.

[60] Rao, V.S., Prasanthi, S., Shanmukha, K.J.V. and Prasad, K.R.S. (2012): Physico-chemical analysis of water samples of Najendle area in Gunter District of Andhra Pradesh, India Inter. J. Chem. Tech. Res., 4(2):691-699.

[61] Robert, S.B. (1979): Chemistry and Technology of lime and limestone. A Wiley-Interscience Publication, $2^{\text {nd }}$ Edition. pp. 95-158.

[62] Robillard, P.D., Sharpe, W.E. and Swistock, B.R. (2015): How to Interpret a Water Analysis Report; Agricultural and Biological Engineering; College of Agricultural Sciences, U.S. Department of Agriculture and Pennsylvania Counties Cooperating.

[63] Saenz, M., Blasco, J. and Gomez-Parra, A. (2003): Speciation of heavy metals in sediments of three coastal ecosystems in the Gulf of Cadiz, southwest Iberian peninsula. Environmental Toxicology and Chemistry, 22(12):33-39.

[64] Segarra, M.J.B., Prego, R., Wilson, M.J., Bacon, J. and Santos-Echeandia, J. S. (2008): Metal speciation in surface sediments of the Vigo Ria (N.W. Iberian Peninsula), Science Marjor., 72(1): 119-126.

[65] Sekabira, K., Oryem, O. H., Basamba, T. A., Mutumba, G. and Kakudidi, E. (2010):Assessment of heavy metal pollution in the urban stream sediments and its tributaries; Int. J. Environ. Sci. Tech., 7 (3): 435-446.

[66] Serra, R. (2006): Dictionary of Geology. Academic (India) Publishers, New Delhi - 110008.

[67] Soil Quality for Environmental Health (2011): Particulate Organic Matter; retrieved from: http://soilquality.org/indicators/pom.html on 18/03/2015.

[68] Spargo, J., Allen, T. and Kariuki, S. (2013): U-Mass Soil and plant Tissue Testing Laboratory;University of Massachusetts; Interpreting test result, pp 1-4.

[69] Steffen, Robertson and Kirsten (2004), Mine Reclamation in Northwest Territories and Yukson. Department of Indian Affairs and Northern Development.

[70] Swer, S. and Singh, P. (2004): Status of water quality in coal mining areas of Meghaloya, India; Proceeding of National Seminar on Environmental Engineering with Special Emphasis on Mining Environment, NSEEME.

[71] Tekade, P.V., Mohabansi, N. P. and Patil, V. B. (2011): Study of physico-chemical properties of effluents from soap industry in Wardha. Rasayan Journal of Chemistry, 4(2):461-465.

[72] Terus, A. (1995): 'Distribution of different fractions of $\mathrm{Cd}, \mathrm{Zn}, \mathrm{Pb}$ and $\mathrm{Cu}$ in polluted and polluted soils'. Water, Air and Soil Pollution Journal, 83: 1-4.

[73] Tessier, A., Campbell, P.G.C. and Bisson, M. (1979): Sequential Extraction Procedure for the Speciation of Particulate Trace Metals; Analytical Chemistry,51(7): 844- 851.

[74] TOC (2012): Total Organic Carbon, retrieved from: http://water.me.vccs.edu/exam_prep/TOC.html on the 23/01/2015.

[75] Trivedi, R.K. and Goel, P.K. (1984): Chemical and biological methods for water pollution studies.Karad Environmental Publication, pp1-251.

[76] USEPA (2008): Region 4: Laboratory and Field Operations - PM 2.5: Objectives and History. As available at en.wikipedia.org/wiki/particulate.

[77] USEPA (1996a): Report: recent Developments for In Situ Treatment of Metals contaminated Soils, U.S. Environmental Protection Agency, Office of Solid Waste and Emergency Response.

[78] Vogel's (2008): Text book of quantitative chemical analysis. $6^{\text {th }}$ Edition, Prentice Hall, England, pp277.

[79] Walkey, A. and Black, I. A . (1934): An Examination of thedigestion method for the determination of soil organic matter and a proposed chromic acid titration. Soil Science, 37: 29-38.

[80] Wangboje, O.M., Oronsaye, J.A.O., Okieimen, F.E. and Oguzie, F.A. (2014): Chemical Fractionation of Heavy Metals in the Sediments of the Ikpoba Reservoir, Benin City Nigeria. Nigeria journal of applied science. 32: 241-254.

[81] WHO (1973): Guidelines for drinking water quality. $3^{\text {rd }}$ Edn. World Health Organisation, Geneva, Washington, D.C.

[82] WHO (1981): Environmental Health Criteria 17: Manganese. World Health Organization.Geneva, Switzerland.

[83] WHO (1986): Guidelines for drinking water Quality, World Health Organizations Geneva, pp 231.

[84] WHO (1998): World Health Organization, Quality Control Methods for Medicinal Plant Materials, WHO, Geneva, Switzerland.

[85] WHO (1998): Environmental Health Criteria 200: Copper. International Programme on Chemical Safety, World Health Organization: Geneva. 
[86] WHO (1994): Update and Revision of the Air quality guidelines for Europe.

[87] WHO (2002): Environmental Health Criteria 228: Principles and methods for the assessment of risk from essential trace elements. World Health Organization: Geneva, Switzerland.

[88] WHO (2004): Rolling revision of the WHO guidelines for drinking-water quality. Draft for review and comments, nitrates and nitrites in drinking water. World Health Organization. (WHO/SDE/WSH/04.08/56).

[89] WHO (2008): Guidelines for drinking water quality 3rd. Edition incorporating the first and second agenda volume 1 Recommendations, World Health Organizations Geneva.

[90] WHO (2014): WHO Regional Office for Europe Report No. EUR/ICP/EHAZ 94-05/PB01. p. 14.

[91] Zhang, S. (1989): Geochemical characteristics of heavy metals in the Xiangjiang river China. In PG. Sly and BT. Hard (ed). Interaction between sediments and freshwater; Kluwer Academic Publisher, London, $253-262$.

Citation: Onivefu Paul Asishana, BalaAnegbe, "Synthesis Baseline Levels of the Chemical Parameters in the Vicinity of Quarry Industries in Igarra, Akoko Edo Local Government, Edo State”, International Journal of Advanced Research in Chemical Science, 7(4), pp. 13-35. DOI: https:// doi.org/10.20431/23490403.0704003

Copyright: (C) 2020 Authors, This is an open-access article distributed under the terms of the Creative Commons Attribution License, which permits unrestricted use, distribution, and reproduction in any medium, provided the original author and source are credited. 